\title{
Development of a Supercritical Carbon Dioxide Brayton Cycle: Improving PBR Efficiency and Testing Material Compatibility
}

Project Number: 02-190

Nuclear Energy Research Initiative

Report for October 2004 to September 2004

Chang Oh

Thomas Lillo

William Windes

Terry Totemeier

Richard Moore

October 2004

Idaho National Engineering and Environmental Laboratory

Bechtel BWXT Idaho, LLC 


\section{Development of a Supercritical Carbon Dioxide Brayton Cycle: Improving PBR Efficiency and Testing Material Compatibility}

Chang Oh, Idaho National Engineering and Environmental Laboratory (INEEL)

Thomas Lillo, William Windes, Terry Totemeier, Richard Moore, INEEL

October 2004

Idaho National Engineering and Environmental Laboratory

Idaho Falls, Idaho 83415

Prepared for the

U.S. Department of Energy

Office of Nuclear Energy

Under DOE Idaho Operations Office

Contract DE-AC07-99ID13727 


\section{CONTENTS}

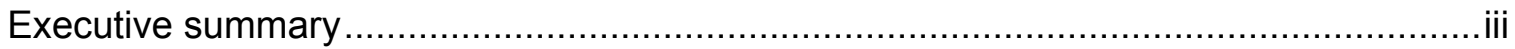

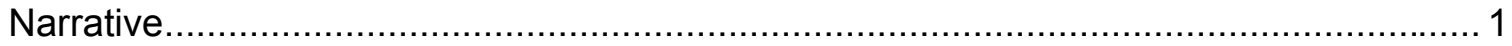

Task 1. Development of $\mathrm{CO}_{2}$ Brayton Cycle ................................................ 1

Task 1-1 Development of the efficiency equation of turbine and compressor for real gas................................................................ 1

Task 1-2 Comparison of supercritical $\mathrm{CO}_{2}$ properties with

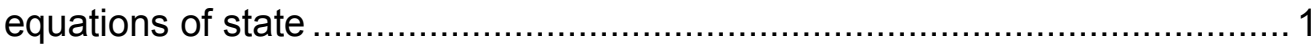

Task 1-3 Selection of the optimization computer code ............................... 1

Task 1-4 Layout of the CO2 thermal cycle and initial

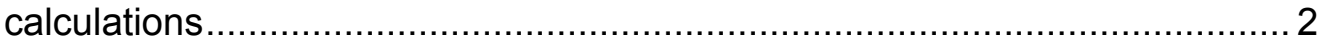

Task 1-5 Perform baseline calculations along with Task 1-4 ..................... 2

Task 2. Improvement of PBR Net Efficiency ............................................... 2

Task 2-1 Parametric study due to enhancement of each component's efficiency ........................................................................ 2

Task 2-2 Optimization of PBR Plant .................................................. 10

Task 2-3 Efficiency Calculations and Other Technical Issues..................... 13

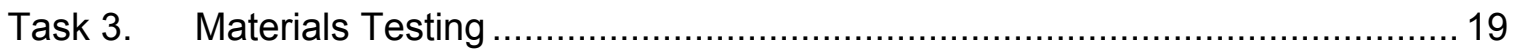

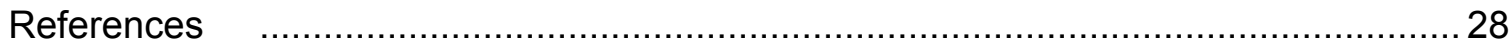




\title{
NUCLEAR ENERGY RESEARCH INITIATIVE
}

\section{Development of a Supercritical Carbon Dioxide Brayton Cycle: Improving PBR Efficiency and Testing Material Compatibility}

\author{
PI: \\ Chang Oh, Idaho National Engineering and Environmental \\ Laboratory (INEEL) \\ Collaborators: \\ Thomas Lillo, William Windes, Terry Totemeier, Richard Moore, \\ INEEL \\ Project Start Date: October $2003 \quad$ Project Number: 02-190 \\ Projected End Date: September 2004
}

\section{Research Objectives}

The U.S. and other countries address major challenges related to energy security and the environmental impacts of fossil fuels. Solutions to these issues include carbon-free electricity generation and hydrogen production for fuel cell car, fertilizer synthesis, petroleum refining, and other applications. The Very High Temperature Gas Reactor (HTGR) has been recognized as a promising technology for high efficiency electricity generation and high temperature process heat applications. Therefore, the U.S. needs to make the HTGR intrinsically safe and proliferation-resistant. The U.S. and the world, however, must still overcome certain technical issues and the cost barrier before it can be built in the U.S. The establishment of a nuclear power cost goal of 3.3 cents $/ \mathrm{kWh}$ is desirable in order to compete with fossil combined-cycle, gas turbine power generation. This goal requires approximately a $30 \%$ reduction in power cost for state-of-the-art nuclear plants. It has been demonstrated that this large cost differential can be overcome only by technology improvements that lead to a combination of better efficiency and more compatible reactor materials.

The objectives of this research are (1) to develop a supercritical carbon dioxide Brayton cycle in the secondary power conversion side that can be applied to some Generation-IV reactors such as the HTGR and supercritical water reactor, (2) to improve the plant net efficiency by using the carbon dioxide Brayton cycle, and (3) to test material compatibility at high temperatures and pressures. The reduced volumetric flow rate of carbon dioxide due to higher density compared to helium will reduce compression work, which eventually increase turbine work enhancing the plant net efficiency.

\section{$\underline{\text { Research Progress }}$}

Advanced gas reactor technology has been identified as one of the best passively safe, thermally efficient, proliferation resistant, modular reactor systems capable of electricity and hydrogen production as well as efficient burning of spent fuel. Internationally, the HTGR concept has become the top priority for implementation because of its inherent safety and near-term implementation feasibility. The U.S. Department of Energy (DOE) 
indicates that the Next Generation Nuclear Plant (NGNP) will be built at the INEEL site by 2017. In order to resolve any first of a kind technical issue, this project consists of three major tasks with a number of subtasks under the major ones. All tasks have been performed on schedule and budget. The technical accomplishments from each task are summarized below:

Development of $\mathrm{CO}_{2}$ Brayton Cycle: The proposed supercritical Brayton cycle deals with high pressures and temperatures. At these conditions, an ideal gas law, using isentropic compression and expansion cannot be applied because of real gas effects associated with non-ideal compression and expansion processes. Therefore, there was a need to develop analytical equations for polytropic expansion and compression through a sequence of turbines and compressors, respectively. The developed set of equations is used for scoping analyses aimed at investigating the effect of the overall plant efficiency. For the detailed computation of the balance of plant (BOP) efficiency calculations, a $\mathrm{CO}_{2}$ database is required to make accurate calculations. We compared a number of equations of state and $\mathrm{CO}_{2}$ databases and determined that the $\mathrm{NIST} \mathrm{CO}_{2}$ database is the most accurate and the properties are consistent with those referenced in Perry's Handbook. We also investigated and compared Aspen Plus and HYSYS for BOP process optimization. Both codes agree well with conditions defined in a simple reference design. The deviation in results was less than $0.5 \%$. However, Aspen Plus is limited to isentropic expansion processes without multiple turbine performance curve capabilities. Therefore we decided to use the HYSYS code for our BOP calculations. We also used a numerical model that was originally developed at MIT using the Visual Basic computer language. This numerical model was revised by INEEL by implementing the NIST $\mathrm{CO}_{2}$ database and adding a reactor core pressure drop equation to the numerical model. The results from HYSYS were compared with those from the VisualBasic (V-B) model. The results produced by both models agreed very well for the 3-shaft baseline case. The HYSYS $\mathrm{CO}_{2}$ Brayton cycle model gives a $51 \%$ plant efficiency, which is an improvement over the $47 \%$ for the helium Brayton cycle using the same BOP layout. The improvement in efficiency is attributed to the reduced volumetric flow of $\mathrm{CO}_{2}$ over that of helium, which results in less compression work.

Improvement of HTGR Net efficiency: The objective of this task is to determine the overall plant cycle efficiency by the integration and optimization of each of the components used in the power conversion side. In order to perform this task in an efficient manner, our original reference design with a three-shaft turbo-machinery arrangement was used in a parametric study and optimization with helium as working fluid using HYSYS. In parallel to the use of HYSYS, the V-B model was used with an implementation of an appropriate friction pressure drop equation for a pebble bed reactor. This term is importance in determining the net power plant efficiency and is not directly calculated by the HYSYS model. A similar pressure drop equation can be input for a prismatic core of NGNP. After the helium Brayton Cycle loop was optimized a number of HYSYS simulations with supercritical $\mathrm{CO}_{2}$ were completed.

A number of important parameters were investigated for this study. The parameters investigated are: various temperature differences across the reactor, reactor inlet temperatures, inlet cooling temperatures to compressors, effectiveness factor of the IHX and recuperator, efficiencies of the compressors, turbines, and other components. Results corresponding to various temperature differences across the reactor for a threeshaft $250 \mathrm{MW}$ thermal helium Brayton cycle using a $92 \%$ effectiveness factor for the intermediate heat exchange and $90 \%$ polytropic efficiency for the turbines and 
compressors, indicate that at a relatively low reactor outlet temperature $\left(850^{\circ} \mathrm{C}\right)$, the maximum cycle efficiency peaks at $45 \%$, which corresponds to a reactor inlet temperature of $520^{\circ} \mathrm{C}$. As the reactor outlet temperature is allowed to increase, the maximum efficiency increases to $51.5 \%$ at an outlet temperature of $1000^{\circ} \mathrm{C}$. For intermediate outlet temperature between $850^{\circ} \mathrm{C}$ and $1000^{\circ} \mathrm{C}$, the cycle efficiency increases from $45 \%$ to $51.5 \%$ with the corresponding reactor inlet temperature increasing from $520^{\circ} \mathrm{C}$ to $640^{\circ} \mathrm{C}$. The effect of compressor efficiency on the overall Brayton cycle efficiency was determined by varying the compressor efficiency from 90 to $94 \%$ using a constant reactor inlet and outlet temperature of $500^{\circ} \mathrm{C}$ and $900^{\circ} \mathrm{C}$, respectively. The results showed that the cycle efficiency increases from $48.2 \%$ for a compressor polytropic efficiency of $90 \%$ to $50.2 \%$ for a polytropic efficiency of $94 \%$. A practical way of reducing the compressor work is to keep the specific volume of the gas as small as possible during the polytropic compression. This can be achieved by maintaining the gas temperature as low as possible because specific volume is proportional to temperature. By dividing the compression process into stages and cooling the gas between stages, the total work done during the compression process is reduced. By reducing the compressor inlet temperature by $5^{\circ} \mathrm{C}$, the overall cycle efficiency increases by $0.65 \%$. We also investigated the sensitivity of the effectiveness of the intermediate heat exchanger (IHX) on the overall cycle efficiency. If the effectiveness of the IHX is improved from $90 \%$ to $92 \%$ at a core outlet temperature of $950^{\circ} \mathrm{C}$ and a core inlet temperature of $400^{\circ} \mathrm{C}$, for example, there is an initial improvement of the overall Brayton efficiency by $0.65 \%$. The IHX effectiveness has less impact on the efficiency compared to the compressor efficiency.

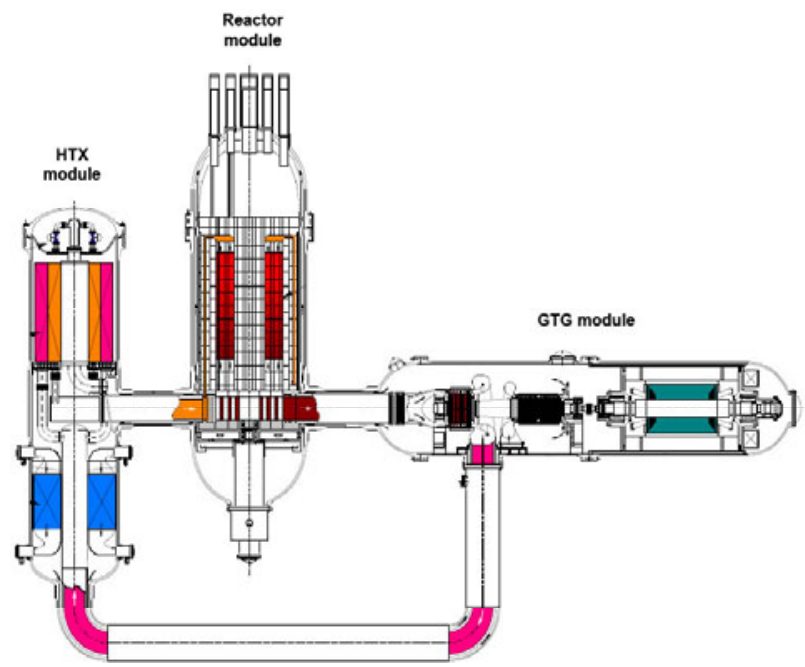

Fig. E-1. GTHTR-300
In order to validate the HYSYS and V$B$ models, a simple one-shaft Brayton cycle layout and reference design of the GTHTR300 was used. GTHTR300 is a direct cycle plant that consists of three subsystem modules including a reactor with a prismatic core, a gas turbine generator module with one turbine, one compressor, and a generator on a single shaft in a horizontal arrangement, and a heat exchanger module with one recuperator and one precooler as shown in Figure E-1.

Assumed values of turbine polytropic efficiency (92.8\%), compressor polytropic efficiency (90.5\%), recuperator effectiveness (95\%), and inlet compressor temperature $\left(28^{\circ} \mathrm{C}\right)$ were used along with same conditions of other parameters in both the V-B and HYSYS models. The V-B model gives lower net cycle efficiencies than those of HYSYS except at the maximum efficiency point. The one difference between the HYSYS and V$B$ models lies in the uses of different helium property database. The $V-B$ model uses the NIST database while HYSYS uses an equation of state to define the helium properties. Then in order to check the accuracy of HYSYS simulation using $\mathrm{CO}_{2}$, a $\mathrm{CO}_{2}$ pressureenthalpy diagram was used. The results calculated by HYSYS agree very well with those calculated using the $\mathrm{CO}_{2}$ pressure-enthalpy diagram. 
A parametric investigation was made with supercritical $\mathrm{CO}_{2}$ cycle using a $250 \mathrm{MW}$ threeshaft reference design. Three different $\mathrm{CO}_{2}$ secondary system pressures of $6.3 \mathrm{MPa}, 13$ $\mathrm{MPa}$, and $20 \mathrm{MPa}$, give cycle efficiency of $48 \%, 49.3 \%$, and $50.3 \%$, respectively, which are not significantly different from each other.

Working fluids of helium for both direct and indirect cycle, nitrogen for indirect cycle, and $\mathrm{CO}_{2}$ for indirect cycle were investigated. The difference between the helium direct cycle and the indirect cycle was $50.9 \%$ vs. $48.7 \%$ respectively. Nitrogen gave a cycle efficiency of $45.5 \%$ while $\mathrm{CO}_{2}$ gave a cycle efficiency of $50.7 \%$. Total area ratio (total heat transfer area of working fluid / total heat transfer area of helium indirect cycle) gives, 0.65 for helium direct cycle, unity for helium indirect cycle, 1.32 for nitrogen indirect cycle, and 1.18 for $\mathrm{CO}_{2}$ indirect cycle at $20 \mathrm{MPa}$. Conclusions from the investigation are (1) among the three working fluids studied, $\mathrm{CO}_{2}$ has the highest cycle efficiency due to less compression. $\mathrm{CO}_{2}$ cycle also results in the smallest turbomachinary, and (2) helium direct cycle eliminates the IHX and consequently requires the smallest heat transfer area due to the higher heat capacity and thermal conductivity than those of the other fluids considered.

Theoretically a combination of reheat and intercooling increases the cycle efficiency in a closed loop. Preliminary multiple reheat with a number of intercooling were investigated using a molten salt (Flibe) in the primary side and helium in the power conversion loop. This configuration yields a $56 \%$ cycle efficiency. Further investigation using Flibe- $\mathrm{CO}_{2}$ is being considered.

Material Compatibility: Research on the creep behavior and corrosion resistance in supercritical $\mathrm{CO}_{2}$ of MA 754 continued during FY04. The creep behavior of both coarsegrained as well as fine-grained MA 754 was documented. Creep microstructures were documented and fracture analysis was carried out on failed creep samples. A manuscript documenting the results was prepared and submitted to a peer-reviewed journal for publication. The results showed that MA 754 did, indeed, exhibit superior creep resistance at temperatures approaching $1000^{\circ} \mathrm{C}$. The material did, however, exhibit lower creep rates in direction perpendicular to the extrusion direction, i.e. creep rate is a function of direction in the material, and exhibited low creep ductility, $<1 \%$, at elevated temperatures. Fine-grained MA 754 exhibited lower creep resistance but higher creep ductility.

Final modifications were made to a supercritical $\mathrm{CO}_{2}$ loop and the corrosion behavior of MA 754 in flowing supercritical $\mathrm{CO}_{2}$ at $1000^{\circ} \mathrm{C}$ and 1500 psi was documented. Experiments were carried out at exposure times ranging from 47 to 335 hours. The time-averaged corrosion rate was found to decrease as the exposure time increased. The corrosion rate at the 335-hour exposure test equated to less than $1 \mathrm{~mm} / \mathrm{year}$. Microscopic examination indicated that a corrosion layer formed and grew slowly. The corrosion layer also acted to protect the base material from further corrosion.

Overall, it was concluded that MA 754 possessed high creep resistance at $1000^{\circ} \mathrm{C}$, better than other high temperature metallic alloys, and acceptable corrosion resistance to supercritical $\mathrm{CO}_{2}$. It would appear that MA 754 is acceptable for application in components of as supercritical Brayton cycle. 
Highlights of the annual activities are summarized below:

- In terms of the schedule and budget, we are right at the target.

- Task 1 (development of $\mathrm{CO}_{2}$ Brayton cycle) including a number of baseline calculations has been completed.

- Upon completion of Task 1, we mainly focused on Task 2. Parametric studies have been performed to determine the overall cycle efficiency sensitivity to key parameters.

- For supercritical $\mathrm{CO}_{2}$ Brayton cycle, a case from a HYSYS simulation was checked to make sure that exit conditions of a compressor calculated using HYSYS agreed with those from the $\mathrm{CO}_{2}$ pressure-enthalpy diagram through sequential compression steps. They agree very well.

- Among three working fluids studied for the indirect power conversion study (PCS), supercritical $\mathrm{CO}_{2}$ has the highest cycle efficiency due to less compression work as a result of the higher densities of supercritical $\mathrm{CO}_{2}$ than other fluids used for the indirect cycle. Supercritical $\mathrm{CO}_{2}$ also results in the smallest turbomachinary components.

- Helium direct cycle eliminates an IHX and consequently requires the smallest heat transfer area due to the higher heat capacity and thermal conductivity than those of other fluids.

- For the final selection of the best working fluid, or fluid mixture, trade-off studies need to be performed for efficiency, capital cost, maintenance cost, the stability of fluids through compressor, potential leakage from PCS, and other relevant issues. This project will include some of these issues later in FY-05 efforts.

- Two technical papers were published and one paper was accepted in peer review journal.

C.H. Oh, R. Moore, Enhancement of the Thermal Efficiency for High Temperature Gas-Cooled Reactors, the $10^{\text {th }}$ International Topical Meeting on Nuclear Reactor Thermal Hydraulics, Seoul, Korea, October 5-9, 2003.

C.H. Oh and R.L. Moore, Parametric Investigation of Brayton Cycle for High Temperature Gas-Cooled Reactors, ASME Summer Heat Transfer Conference, Charlotte, NC, July 11-15, 2004.

C.H. Oh and R.L. Moore, Brayton Cycle for High Temperature Gas-Cooled Reactors, to be published in March Issue of Nuclear Technology, 2005.

- Completed Task 3-1 - Characterization of creep deformation of coarse-grain MA 754 that included completion of subtasks 3-1-2 High temperature mechanical and creep properties of coarse-grained MA 754 and 3-1-3 Mechanical and creep properties of fine-grained MA 754. A manuscript describing the results was accepted for publication in a peer-reviewed journal.

T. C. Totemeier, and T. M. Lillo, Effect of Orientation on the Tensile and Creep Properties of Coarse-Grained INCONEL Alloy MA754, accepted for publication in Metallurgical and Materials Transactions A.

- Completed subtask 3-2-2 Corrosion testing of MA 754 in supercritical $\mathrm{CO}_{2}$

- $\quad$ Characterized the creep microstructures of MA 754. These results were also incorporated into the manuscript mentioned under Task 3-1 above. 


\section{Planned Activities}

- Task 2 continues with comparison of other cycle configurations.

- Other cycle configurations are a combined cycle, recompression, and multiple reheat cycle. The cycle will be optimized using HYSYS.

- If time is allowed, an intermediate flow loop heat transfer study for NGNP hydrogen will be investigated.

- Complete Task 3-2-3 Corrosion testing of fine-grain MA 754 and compare the corrosion behavior to coarse-grained MA 754

- Initiate and complete Task 3-2-3 Corrosion testing of alternate alloys. Tentatively we plan on documenting the corrosion behavior of I-617, an alloy receiving considerable attention for use in various high temperature areas of the NGNP.

- Complete the summary report on MA 754 (Task 3-3) with recommendations on the suitability of MA 754 for use in a supercritical Brayton cycle. 


\section{Narrative}

\section{Task 1. Development of $\mathrm{CO}_{2}$ Brayton Cycle}

Task 1-1 Development of the efficiency equation of turbine and compressor for the real gas

The objective of this task involves mathematical derivations of the turbine and compressor efficiency. When supercritical $\mathrm{CO}_{2}$ gas is expanded and compressed in a real gas fashion through a sequence of turbines and compressors, the isentropic formulas shown in most thermodynamic books are no longer useful.

Task technical status overview: As reported in the first annual report the following tasks were already accomplished through the end of September 2002.

- $\quad$ Theoretical equations for polytropic expansion and compression were developed in this task for scoping analyses in Year 1.

Task 1-2 Comparison of supercritical $\mathrm{CO}_{2}$ properties with equations of state

The objective of this task involves checking thermal and transport properties of $\mathrm{CO}_{2}$ gas between references (Reid et al., 1977, Reid et a., 1987, Rivken, 1988, and Perry et al., 1997 ) and a number of equations of state (EOS) in the Aspen Plus (Aspentech, 2001) and HYSYS codes (Aspentech, 2001).

Task technical status overview: As reported in the first annual report the following tasks were already accomplished through the end of September 2002.

- Thermal and transport properties of $\mathrm{CO}_{2}$ were compared and we found that the NIST database (http://webbook.nist.gov/chemistry/fluid) is very accurate. Also the LeeKesler-Plocker equation of state is the most accurate EOS defined in Aspen Plus and HYSYS. The Peng-Robinson EOS (Peng and Robinson, 1976) is good for helium and other fluids. Therefore, the NIST database is used for our scoping calculations and the Lee-Kesler-Plocker EOS (Knapp, $\mathrm{H}$., 1989) is used for all the $\mathrm{CO}_{2}$ computer simulation while the Peng-Robinson EOS is used for helium and other fluids.

\section{Task 1-3 Selection of the optimization computer code}

The objective of this task involves the comparison of the HYSYS and Aspen Plus codes and the selection of one code for Next Generation Nuclear Plant (NGNP) (Macdonald, 2003) simulations.

Task technical status overview: As reported in the first annual report the following tasks were already accomplished through the end of September 2002. 
- $\quad$ Actually both the HYSYS and ASPEN PLUS computer codes gave the same results for cases we investigated. However, HYSYS has more capabilities than those for Aspen Plus. If more complicated chemical processes are involved, Aspen Plus can be a better code. However, when it is applied to no chemical reaction application with polytropic compression and expansion, HYSYS is a slightly better code with more characteristic turbine curves. INEEL has had company wide licenses for both computer codes. Therefore, we can use Aspen Pus code for other application such as hydrogen production plant.

Task 1-4 Layout of the $\mathrm{CO}_{2}$ thermal cycle and initial calculations

The objective of this task is to create a preliminary layout of a $\mathrm{CO}_{2}$ thermal cycle as a baseline case for comparing with the helium cycle.

Task technical status overview: As reported in the first annual report the following tasks were already accomplished through the end of September 2002.

Task 1-5 Perform baseline calculations along with Task 1-4

The objective of this task is to establish a baseline case and to use the baseline case as a basis for comparing its results with those from other cycle efficiency calculations using other cycle configurations and various working fluids.

Task technical status overview: This task was completed in June 2003.

\section{Task 2. Improvement of Pebble Bed Reactor (PBR) Net Efficiency}

Task 2-1 Parametric study due to enhancement of each component's efficiency

The objective of this task is to determine the overall plant busbar efficiency by the combination of the increased efficiency of each component in the secondary side of the HTGR. To accomplish this task, we performed a parametric study of the effect of each component on the overall Brayton cycle efficiency.

Important parameters for improving the Brayton cycle efficiency are increasing the reactor core outlet temperature, increasing the efficiencies of the compressor, turbine, intermediate heat exchanger, and others. The reactor core outlet temperature was varied between $850^{\circ} \mathrm{C}$ and $1000^{\circ} \mathrm{C}$. For each of the fixed outlet temperatures $\left(850^{\circ} \mathrm{C}\right.$, $900^{\circ} \mathrm{C}, 950^{\circ} \mathrm{C}$ and $1000^{\circ} \mathrm{C}$ ), the inlet temperature to the core was varied between $400^{\circ} \mathrm{C}$ and $640^{\circ} \mathrm{C}$. All of the above cases are based on a three shaft arrangement for the helium Brayton cycle, using an intermediate heat exchanger effectiveness factor of 92 $\%$, a $90 \%$ polytropic efficiency for the compressors and turbines, and a $30^{\circ} \mathrm{C}$ cooling temperature to the precooler and the three intercoolers.

The mass flow rate through the core needed to remove $250 \mathrm{MW}$ of thermal energy from the reactor core is a function of the required temperature drop across the core. Thus, the pressure drop across the core is a function of the core mass flow rate. Previously we did not account for the effect of the pressure drop on the Brayton cycle efficiency. For these calculations, we used a pressure drop equation shown below that is based on a pebble bed reactor. 
The friction pressure drop $\Delta \mathrm{P}_{\mathrm{f}}$ through a pebble bed of height $\mathrm{H}$ (Oh and Moore, 2004) can be expressed as

$$
\Delta \mathrm{P}_{\mathrm{f}}=\psi \cdot \frac{\mathrm{H}}{\mathrm{d}_{\mathrm{h}}} \cdot \frac{\rho_{\mathrm{ave}}}{2} \cdot \mathrm{U}_{\mathrm{p}}^{2}
$$

where $\psi$ is the pressure drop coefficient, $\mathrm{H}$ is the height of the core, $\mathrm{d}_{\mathrm{h}}$ is the hydraulic diameter, $\rho_{\text {ave }}$ is the average density of the fluid in the core, and $U_{p}$ is the mean velocity in the gaps between the particles.

The new V-B numerical model with the new pressure drop correlation was benchmarked against a three-shaft baseline case based on HYSIS simulation. The results and comparison are shown in Table 1.

Table 1. Comparison between HYSIS simulation and Visual-Basic based model.

\begin{tabular}{|l|l|l|l|l|l|}
\hline $\begin{array}{l}\text { Calculation } \\
\text { Method }\end{array}$ & $\begin{array}{l}\text { Inlet } \\
\text { temperature / } \\
\text { pressure to } \\
\text { HP turbine }\end{array}$ & $\begin{array}{l}\text { Outlet } \\
\text { temperature/press } \\
\text { ure to HP } \\
\text { compressor }\end{array}$ & $\begin{array}{l}\text { Total } \\
\text { compression } \\
\text { work } \\
(\mathrm{MW})\end{array}$ & $\begin{array}{l}\text { Total } \\
\text { turbine } \\
\text { work } \\
(\mathrm{MW})\end{array}$ & $\begin{array}{l}\text { Busbar } \\
\text { efficiency }\end{array}$ \\
\hline HYSIS & $\begin{array}{l}865^{\circ} \mathrm{C} / \\
746 \mathrm{MPa}\end{array}$ & $74.5^{\circ} \mathrm{C} / 7.9 \mathrm{MPA}$ & 111.7 & 129.5 & $47 \%$ \\
\hline V-B Model & $\begin{array}{l}864^{\circ} \mathrm{C} / \\
746 \mathrm{MPa}\end{array}$ & $77.5^{\circ} \mathrm{C} / 8.0 \mathrm{MPA}$ & 112.7 & 129.9 & $46 \%$ \\
\hline
\end{tabular}

Figure 1 shows a three-dimensional plot of the plant busbar efficiency as a function of reactor inlet and outlet temperatures for a three-shaft $250 \mathrm{MW}$ thermal helium Brayton cycle using a $92 \%$ effectiveness factor for the intermediate heat exchange and $90 \%$ polytropic efficiency for the turbines and compressors. 


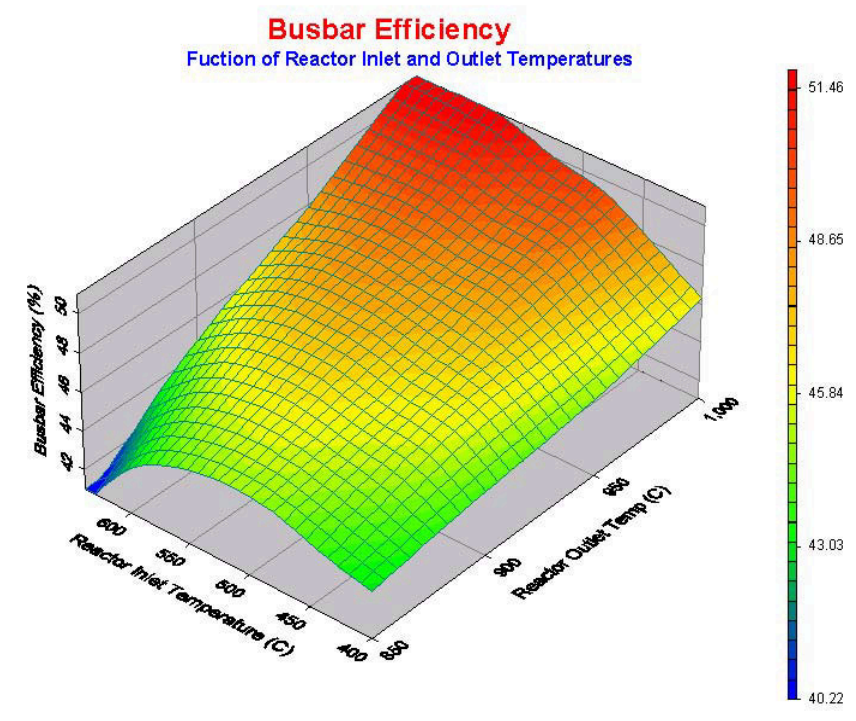

Figure 1. Busbar efficiency as a function of temperature difference across the reactor.

We investigated the effect of compressor efficiency on the overall Brayton cycle efficiency by varying the compressor efficiency from 90 to $94 \%$ as shown in Figure 2.

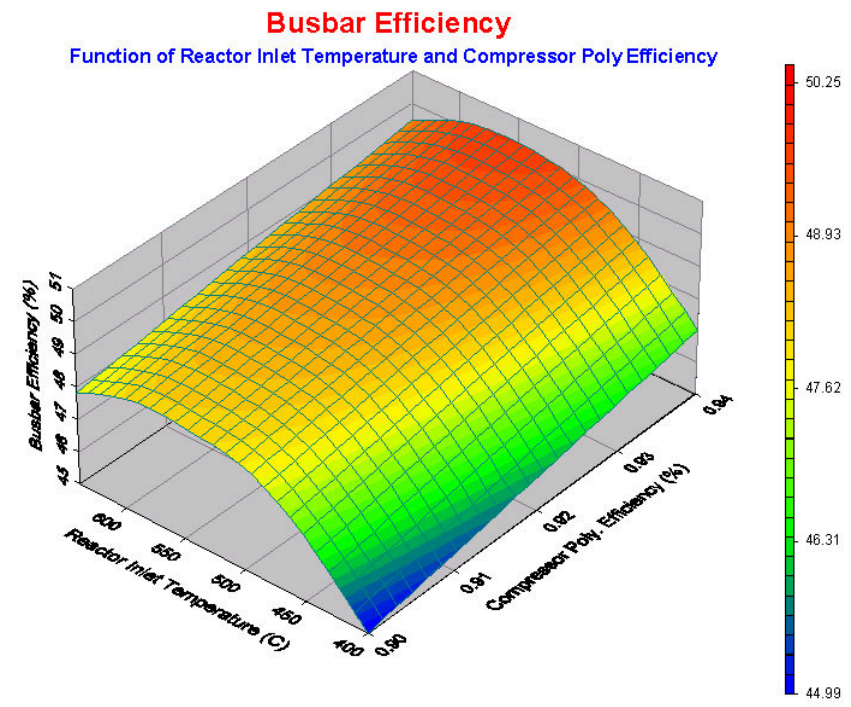

Figure 2. Busbar efficiency as a function of compressor efficiencies and reactor inlet temperatures.

A practical way of reducing compressor work is to keep the specific volume of the gas as small as possible during the polytropic compression. This is achieved by maintaining the temperature of the gas as low as possible because specific volume is proportional to temperature. By dividing the compression process into stages and cooling the gas between stages, the total work done during the compression process is 
reduced. By reducing the compressor inlet temperature by $1^{\circ} \mathrm{C}$, the overall cycle efficiency increases by $0.131 \%$ as shown in Figure 3.

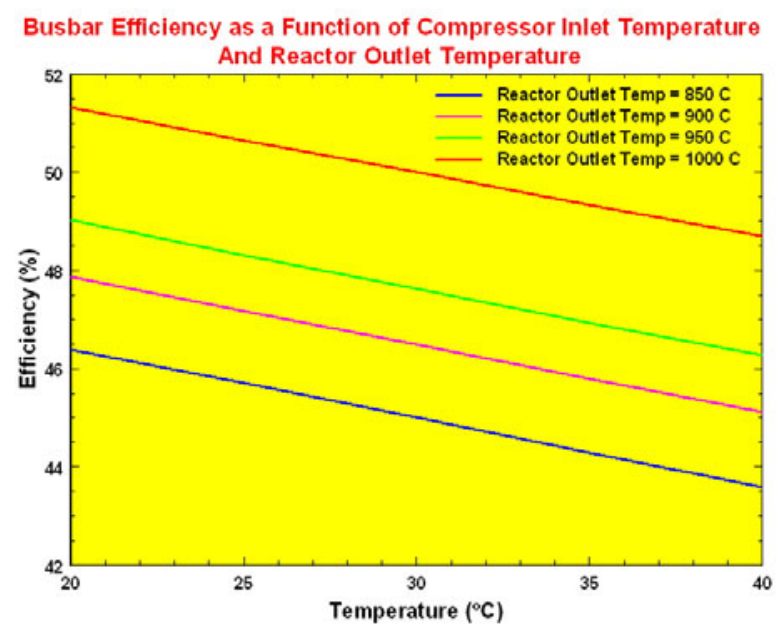

Figure 3. Busbar efficiency at various cooling temperature.

We also investigated the sensitivity of the effectiveness of intermediate heat exchanger (IHX) on the overall busbar efficiency. If the effectiveness of $\mathrm{IHX}$ is improved from $90 \%$ to $92 \%$ at a core outlet temperature of $950^{\circ} \mathrm{C}$ and a core inlet temperature of $400^{\circ} \mathrm{C}$, for example, there is an initial improvement of the overall Brayton efficiency by $0.65 \%$. The IHX effectiveness has less impact on the efficiency compared to the compressor efficiency.

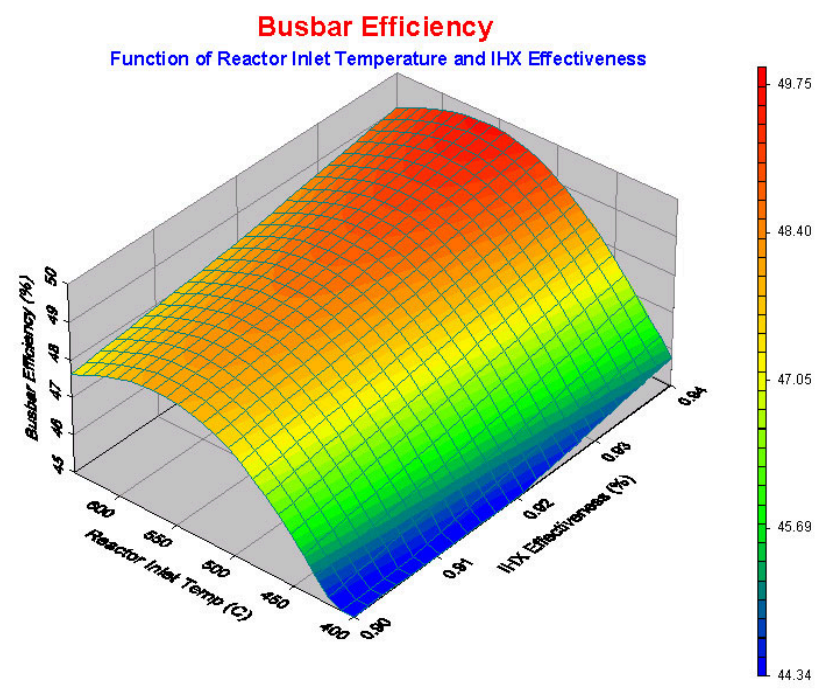

Figure 4. Busbar efficiency as a function of IHX efficiencies and reactor inlet temperatures. 
Figure 5 shows how the temperature difference across the reactor impacts the power turbine inlet temperature that is very important to the overall efficiency.

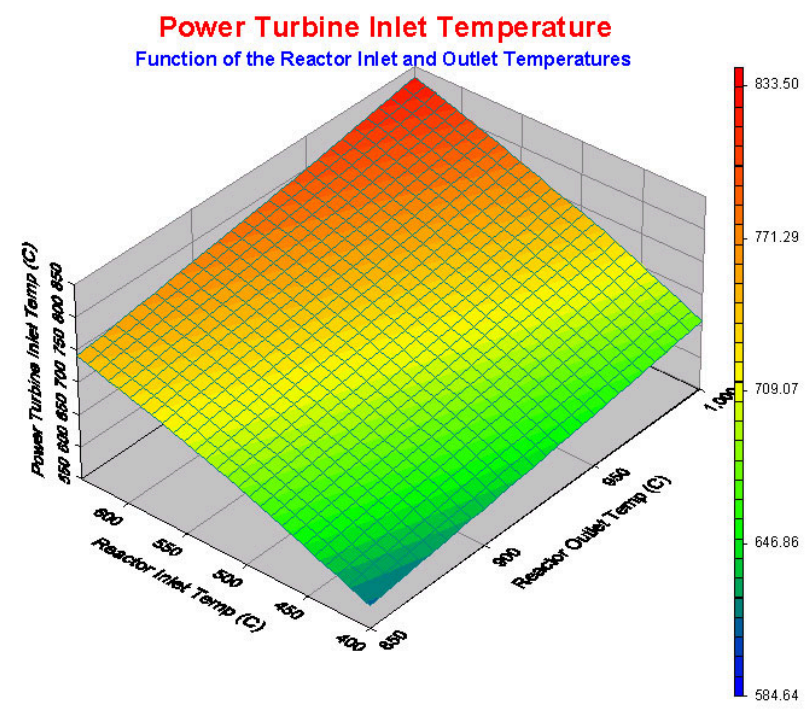

Figure 5. Power turbine inlet temperature as a function of temperature drop across the reactor.

The objective of this task is to determine the overall plant cycle efficiency by the combination of the increased efficiency of each component in the secondary side of the HTGR. To accomplish this task, we performed a number of parametric studies to determine the effect of each component on the overall Brayton cycle efficiency.

In order to calculate the pressure and temperature at the exit of a polytropic expansion or compression process, pressure-enthalpy $(\mathrm{P}-\mathrm{H})$ data from the NIST database was used. The procedure is described below and depicted in graphical form in Figure 6:

(1) Starting Point 1, follow the line of constant entropy to the required discharge pressure of $\mathrm{P}_{2}$, locating the isentropic discharge state point of $2_{\text {is. }}$.

(2) With these two points located, the differential isentropic enthalpy can be calculated from the following equation:

$\Delta \mathrm{h}_{\text {is }}=\mathrm{h}_{\mathrm{i}_{\mathrm{is}}}-\mathrm{h}_{1}$

(3) Calculate the real discharge enthalpy of point 2 using:

$\mathrm{h}_{2}=\frac{\Delta \mathrm{h}_{\text {is }}}{\eta_{\text {is }}}+\mathrm{h}_{1}$

where $\eta_{\text {is }}$ is the isentropic process efficiency. The point 2 is on the same pressure $P_{2}$ line shown on Figure 7. At the point 2, temperature can be obtained on the same temperature isotherm line in Figure 6. 
The actual discharge temperature can now be obtained from the P-H diagram (GPSA, 1998) or P-H database. The helium properties were incorporated as a property look-up table. In these calculations, we used pressure-temperature-enthalpy data from the NIST database.

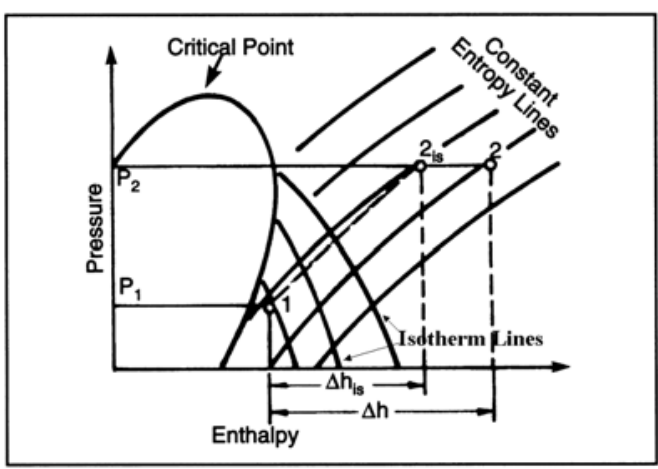

Figure 6. Pressure-Enthalpy diagram.

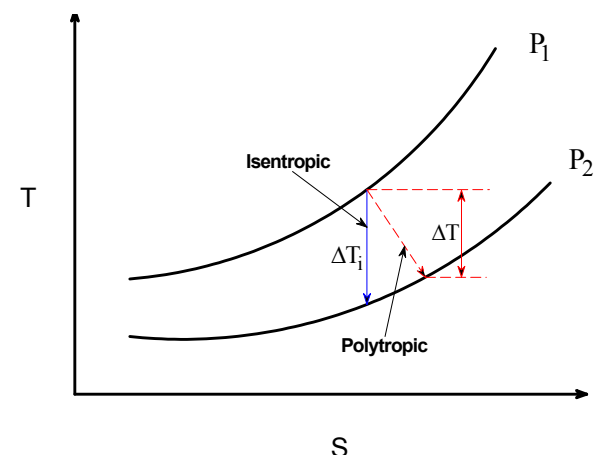

Figure 7. T-S diagram for isentropic and polytropic (real) compression.

In the preceding quarters, we used heat capacities of helium for calculating the stream conditions through all unit-operation components. However, heat capacity of supercritical $\mathrm{CO}_{2}$ has a spiked value around the supercritical condition of pressure of 7.29 $\mathrm{MPa}$ and temperature of $31^{\circ} \mathrm{C}$. Therefore, there was a need to use an enthalpy database for avoiding numerical instabilities when dealing with step increased value of heat capacity around the supercritical condition.

As part of Task 2, improvement of the net efficiency, there was a need to validate our Visual Basics and HYSYS models. Results from both the HYSYS simulation and the Visual Basic model were compared with Japanese calculations based on the $300 \mathrm{MWe}$ GTHGR that was developed by the Japan Atomic Energy Research Institute (JAERI). Figure 8 is a schematic of the GTHTR300 (Yan, 2003) power conversion cycle. As shown, the GTHTR 300-power conversion cycle selected for validation uses no cycle intercooling. 


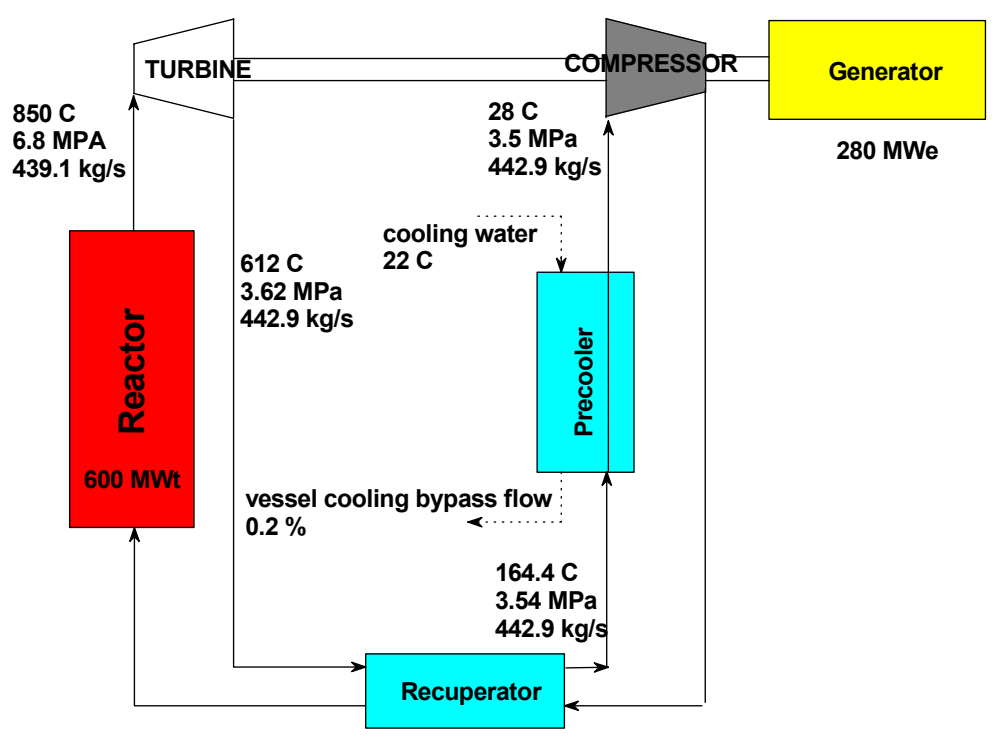

Figure 8. GTHTR300 Schematic.

Figures 9 and 10 show comparisons of cycle efficiencies and pressure ratios, respectively at various reactor inlet temperatures and a reactor outlet temperature of $850^{\circ} \mathrm{C}$. Turbine polytropic efficiency of $92.8 \%$, compressor polytropic efficiency of $90.5 \%$, recuperator efficiency of $95 \%$, and inlet compressor temperature of $28^{\circ} \mathrm{C}$ were used. The Visual Basic model gives lower efficiencies than those of HYSYS except at the maximum efficiency point. The one difference between HYSYS and V-B model lies in a different helium property database. V-B model uses NIST database while HYSYS uses an equation of state to define the helium properties.

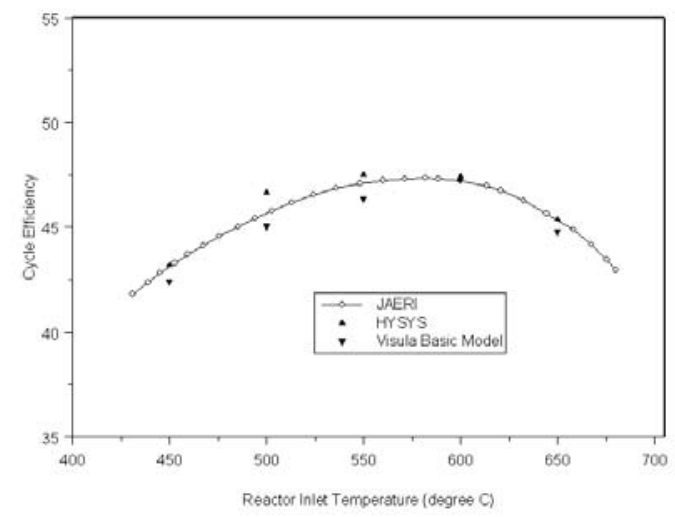

Figure 9. Comparison of cycle efficiency.

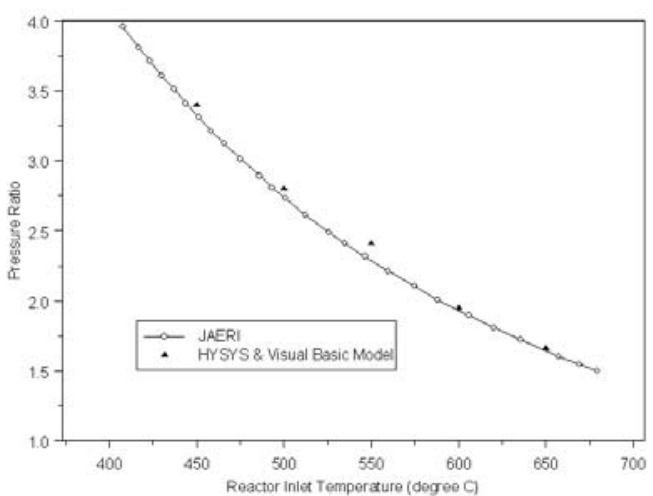

Figure 10. Comparison of pressure ratio

Cycle efficiency is most sensitive to core outlet temperature, which is transferred to the inlet stream of the high-pressure turbine through an intermediate heat exchanger. 
Based on a three-shaft $250 \mathrm{MW}$ thermal HTGR, we summarize cycle sensitivities to key cycle parameters shown in Table 2.

Table 2. Cycle efficiency sensitivity to key cycle parameters.

\begin{tabular}{|l|c|c|}
\hline Cycle parameters & Change in cycle parameter & $\begin{array}{l}\text { Change in cycle efficiency } \\
(\%)\end{array}$ \\
\hline Turbine inlet temperature & $+50^{\circ} \mathrm{C}$ & +2.1 \\
\hline Recuperator efficiency & $+1 \%$ & +1.6 \\
\hline Reactor vessel cooling flow & $+1 \%$ & -1.2 \\
\hline $\begin{array}{l}\text { Compressor inlet } \\
\text { temperature }\end{array}$ & $+5.0^{\circ} \mathrm{C}$ & +0.8 \\
\hline Compressor efficiency & $+1 \%$ & +1.0 \\
\hline Turbine efficiency & $+1 \%$ & \\
\hline
\end{tabular}

In order to check the accuracy of HYSYS simulation, the $\mathrm{CO}_{2}$ pressure-enthalpy diagram was used to compare with HYSYS simulation results. The method used is the same procedure described above. Figures 11 and 12 illustrate how to obtain the HPC exit temperature of $113^{\circ} \mathrm{C}$ from the P-H diagram. Figure 11 shows HYSYS results for one case using $\mathrm{CO}_{2}$ with a $\mathrm{HPC}$ exit temperature of $113^{\circ} \mathrm{C}$. We need to validate this temperature using the P-H diagram shown in Figure 12. As shown in Figure 12, once the red point 2 in step 3 described above is determined, the temperature isotherm line is crossed at $113^{\circ} \mathrm{C}$, which is the same result obtained from the HYSYS simulation.

\section{HPC Exit Temperature Check on CO2 Brayton cycle}

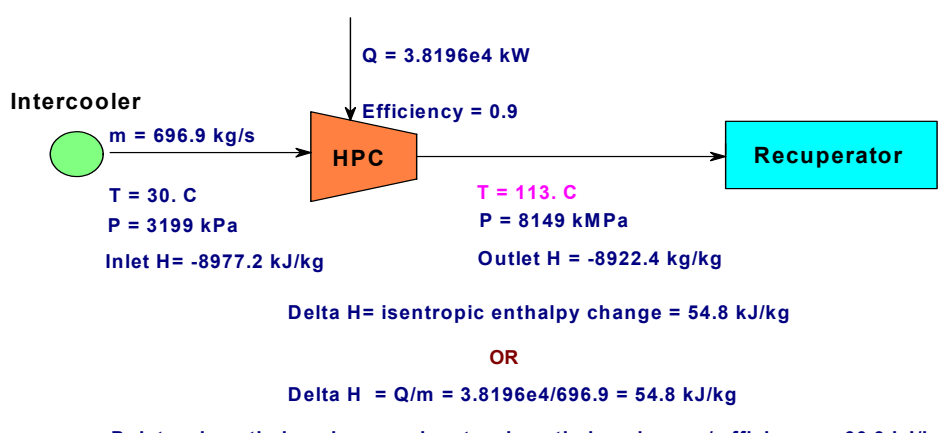

Figure 11. Stream property of the inlet and outlet of the high-pressure compressor from HYSYS simulation. 


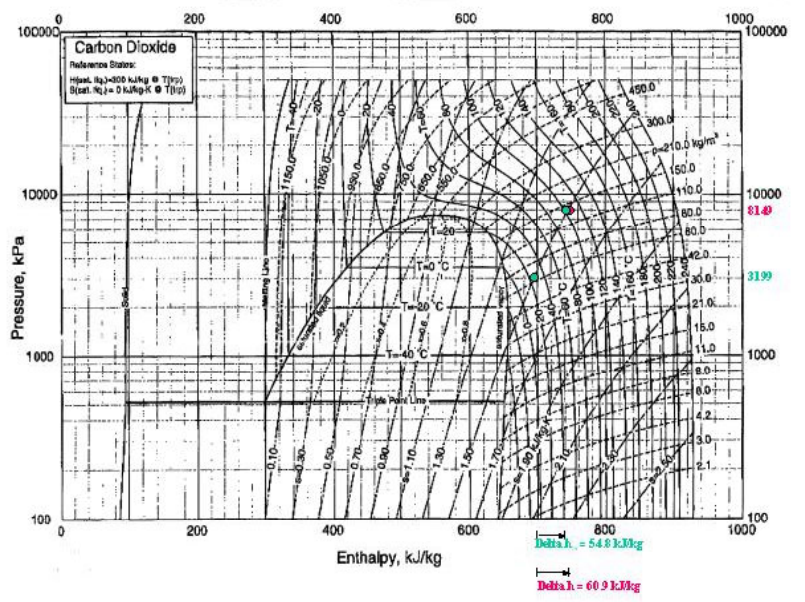

Figure 12. $\mathrm{CO}_{2}$ pressure-enthalpy diagram and paths to obtain the HPC exit temperature of $113^{\circ} \mathrm{C}$.

\section{Task 2-2 Optimization of PBR Plant}

The objective of this task is to improve the overall plant cycle efficiency by the combination of the increased efficiency of each component in the secondary side of the HTGR. To accomplish this task, we performed a number of HYSYS simulation to investigate the pressure effect on the overall cycle efficiency. The high pressure of the working fluid permits the turbo machine to be compact due to the higher density of the fluid. For example, the density of $\mathrm{CO}_{2}$ at $20 \mathrm{MPa}$ and $800^{\circ} \mathrm{C}$ is 2.43 times higher than that of $\mathrm{CO}_{2}$ at $8 \mathrm{MPa}$ and $800^{\circ} \mathrm{C}$. It shows the same trend for helium (2.44 times higher for helium at $20 \mathrm{MPa}$ and $800^{\circ} \mathrm{C}$ than that of helium at $8 \mathrm{MPa}$ and $800^{\circ} \mathrm{C}$ ). Generally system pressure increases the cycle efficiency. However, the optimized system pressure should be determined by energy and mass balance on each component where the condition does not cause temperature crossover around the recuperator and intermediate heat exchanger. The heat transfer of various working fluids affects the final design and operating conditions, which results in various cycle efficiencies. Using HYSYS optimization option, a wide range of system pressures from $6 \mathrm{MPa}$ to $20 \mathrm{MPa}$ were examined along with a wide range of temperatures, which will provide an optimized efficiency.

Figure 13 shows a typical example of a HYSYS simulation using a three-shaft arrangement, a system pressure of $13 \mathrm{MPa}$ and other conditions described as follows: polytropic efficiency of turbine $92 \%$, compressor efficiency of $90 \%$, a reactor outlet temperature of $900^{\circ} \mathrm{C}$, a compressor inlet temperature of $30^{\circ} \mathrm{C}$, three inter coolers $(\mathrm{a}$ pressure drop of $20 \mathrm{kPa}$ each), a recuperator effectiveness of $95 \%$, IHX effectiveness of $90 \%$, pressure drops of $140 \mathrm{kPa}$ for the IHX primary side and $150 \mathrm{kPa}$ for the secondary side, and a pressure drops of $20 \mathrm{kPa}$ for precooler. 


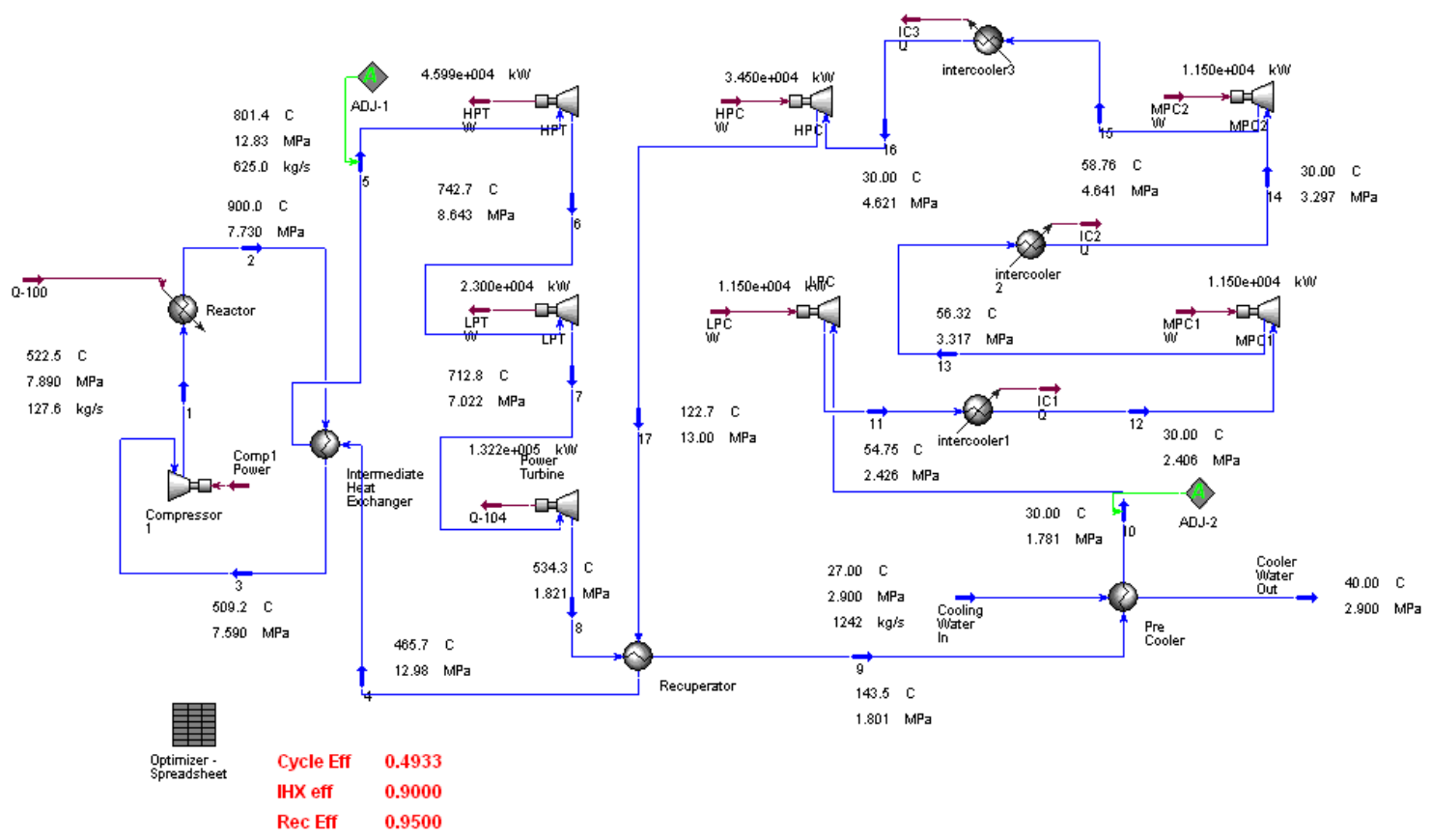

Figure 13. HYSYS Schematic for a supercritical $\mathrm{CO}_{2}$ cycle with $49.3 \%$ efficiency.

The preliminary results of the pressure effect on the cycle efficiency and the size of the recuperator using a supercritical $\mathrm{CO}_{2}$ cycle, indirect 3-shaft arrangement are presented in Table 3.

Table 3. Results of the pressure effect on the efficiency.

\begin{tabular}{|c|c|c|c|}
\hline Pressure in PCS & $\begin{array}{c}\text { Mass flow rate } \\
(\mathrm{kg} / \mathrm{s})\end{array}$ & $\begin{array}{c}\text { UA value for } \\
\text { recuperator (kJ/C- } \\
\mathrm{hr})\end{array}$ & Cycle efficiency \\
\hline $6.3 \mathrm{MPa}$ & 700 & $2.7095 \mathrm{e} 7$ & $48 \%$ \\
\hline $13 \mathrm{MPa}$ & 625 & $1.885 \mathrm{e} 7$ & $49.3 \%$ \\
\hline $20 \mathrm{MPa}$ & 560 & $1.507 \mathrm{e} 7$ & $50.3 \%$ \\
\hline
\end{tabular}

where UA is universal heat transfer coefficient times heat transfer area.

In order to maintain an effectiveness factor of $95 \%$ for the recuperator, the following calculation was implemented into the HYSYS simulation: The effectiveness $\varepsilon$ of a heat exchanger is defined as the ratio of the actual heat transfer rate to the maximum heat transfer rate.

$$
\begin{aligned}
& \varepsilon \equiv \frac{q}{q_{\max }} \\
& q_{\max }=C_{\min }\left(T_{h, i}-T_{c, i}\right)
\end{aligned}
$$

here $\mathrm{C}_{\min }$ is either $\mathrm{C}_{\text {cold }}$ or $\mathrm{C}_{\text {hot }}$, whichever is smaller.

$C_{\text {cold }}=c_{p, \text { cold }} \dot{m}_{\text {cold }}$ 
$C_{h o t}=c_{p, h o t} \dot{m}_{h o t}$

The effectiveness is set for each heat exchanger ( $90 \%$ for the intermediate heat exchanger and $95 \%$ for the recuperator).

Next, the $\mathrm{q}_{\max }$ is determined using equation 4 through 6 . In the case of Helium $\mathrm{c}_{\mathrm{p}}$ is constant through the heat exchanger and $\mathrm{C}_{\min }$ is not a function of temperature.

However, in the case of $\mathrm{CO}_{2}$ or other real gases $\mathrm{C}_{\mathrm{p}}$ is not constant and $\mathrm{C}_{\min }$ is a function of temperature. To account for this, the assumption was made that $c_{p}$ through the heat exchanger would be the average, $c_{p, \text { avg }}$ of $c_{p, \text { in }}$ and $c_{p, \text { out }}$.

In order to fully define a heat exchanger, the inlet and outlet temperature and pressure must be known, along with the mass flow for both the hot and cold side of the heat exchanger. Therefore $q$ of the heat exchanger can be calculated.

HYSYS uses an adjust function to make the heat exchanger satisfy the effectiveness condition. Equations 3 and 4 and the heat exchanger conditions are entered into HYSYS. HYSYS then calculates $\mathrm{q}, \mathrm{q}_{\max }$ and $\varepsilon$ for the exchanger. A modifiable condition is then entered into HYSYS. This condition is adjusted, while the others are held constant, so that the heat exchanger satisfies the effectiveness condition. For the IHX the cold side outlet temperature is adjusted. While for the recuperator the hot side outlet pressure is adjusted. Therefore, if a condition is altered the modifiable condition can be adjusted to satisfy the effectiveness condition.

Direct cycles versus indirect cycles were compared based on a $600 \mathrm{MW}$-thermal Japanese GTHTR and a $900^{\circ} \mathrm{C}$ reactor outlet temperature. Figure 14 shows HYSYS layout for the indirect cycle with $48 \%$ efficiency compared with a $52 \%$ for the direct cycle.

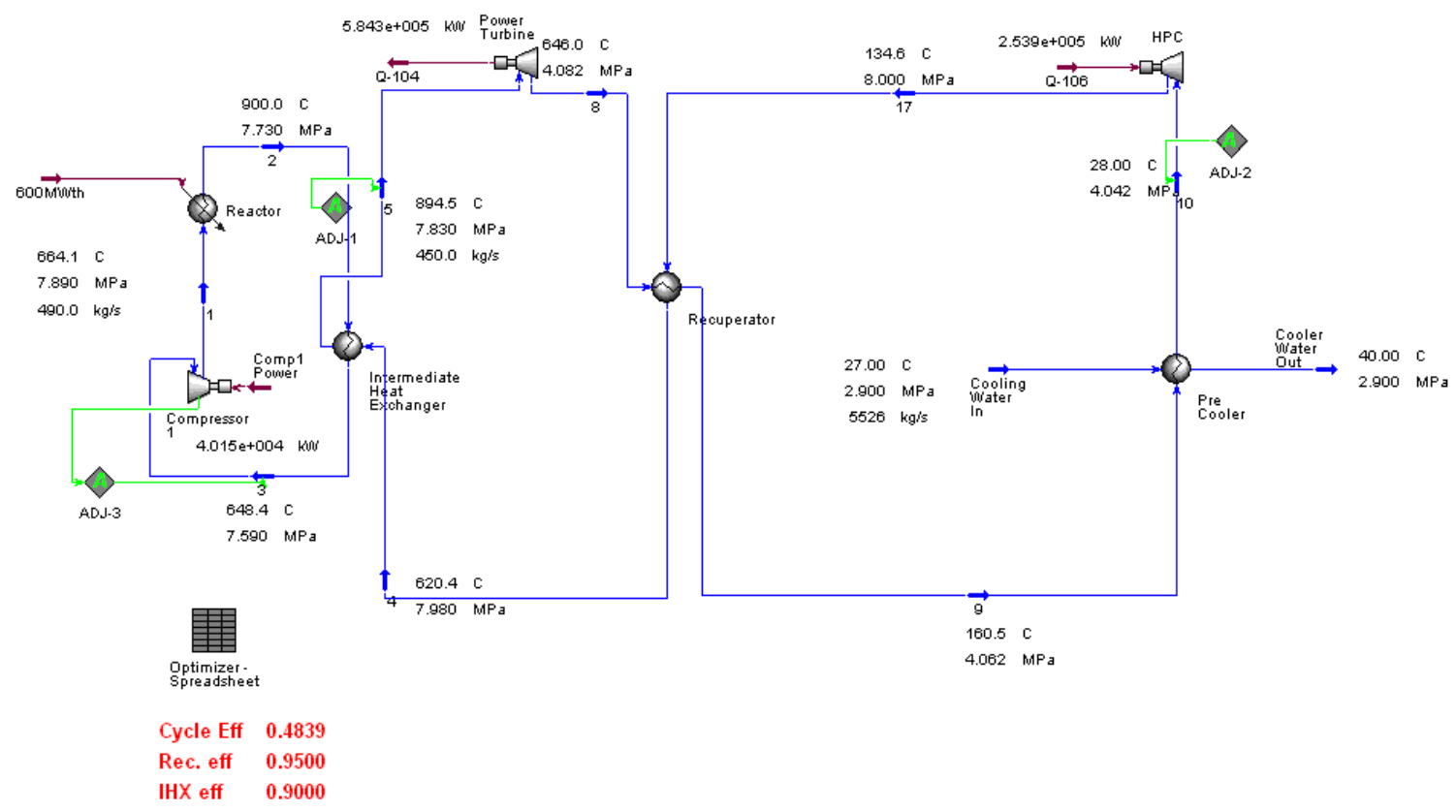

Figure 14. HYSYS layout for the indirect Brayton cycle. 


\section{Task 2-3 Efficiency Calculations and Other Technical Issues}

The objective of this task is to include some of the important technical issues which were not cover in the preceding tasks: review of various working fluids, number of intercooler, an option for reheat, review on other cycles including recompression, a combined Brayton and Rankine cycle, and multiple reheat using molten salts for the intermediate flow loop.

This is the start of the third year of this NERI project thus some preliminary results from this year are presented in this report.

The working fluid is very important for the power conversion system (PCS) of the NGNP. The cycle efficiency, the size of all the components such as turbine, compressor, recuperator, intermediate heat exchanger for hydrogen production units, and other components will depend on the fluid because each different fluid has different heat transfer and transport properties. Due to the different properties of the fluids, the balance of plant will have varying energy and mass balances. The material sustainability in the PCS is also dependent on type of fluids in terms of corrosion, material creep (yield stress, ultimate tensile stress, ductility and others). Construction material used for all the components and piping in the PCS are exposed to high temperature and pressure, which are governed, by the fluid energy and mass balance.

We began to investigate the working fluid choices including nitrogen, and a binary mixture for the indirect cycle. A combined Brayton cycle will also be explored to see the improvement of the efficiency.

\section{2-3-1 Working Fluids}

(a) Helium for both direct and indirect cycle

The direct helium cycle was simulated with an optimal pressure ratio of $\sim 1.93$. This gave a cycle efficiency of $50.9 \%$.

The indirect helium cycle was simulated assuming a compressor outlet pressure of $8 \mathrm{MPa}$. The cycle conditions were optimized with a secondary mass flow rate equal to the primary mass flow $(439.1 \mathrm{~kg} / \mathrm{s})$ and a pressure ratio of $\sim 2.02$. This gave a cycle efficiency of $48.7 \%$.

\section{(b) Nitrogen for indirect cycle}

The indirect Nitrogen cycle was simulated assuming a compressor outlet pressure of $8 \mathrm{MPa}$. The optimal secondary mass flow rate was $2600 \mathrm{~kg} / \mathrm{s}$ and the optimal pressure ratio was $\sim 2.37$. This gave a cycle efficiency of $45.5 \%$.

\section{(c) $\underline{\mathrm{CO}_{2}} \underline{\text { for indirect cycle }}$}

The indirect $\mathrm{CO}_{2}$ cycle was simulated assuming a compressor outlet pressure of $20 \mathrm{MPa}$. The higher compressor outlet pressure was used to take advantage of compression around the critical point and decrease compressor work. The optimal secondary mass flow rate was $1794 \mathrm{~kg} / \mathrm{s}$ and the optimal pressure ratio was $\sim 4.76$. This gave a cycle efficiency of $50.7 \%$. 
The indirect $\mathrm{CO}_{2}$ cycle was also simulated at $8 \mathrm{MPa}$ for comparison. The mass flow rate was unchanged and the optimal pressure ratio was $\sim 6.8$. This gave a cycle efficiency of $46.4 \%$. This is closer to the other working fluid efficiencies. The other working fluids are insensitive to system pressure while an efficiency gain can be accomplished by increasing the pressure for $\mathrm{CO}_{2}$.

Assuming similar pressure drops in the heat exchangers and the same turbomachinary efficiencies, helium, nitrogen, and $\mathrm{CO}_{2}$ at $8 \mathrm{MPa}$ all have approximately the same cycle efficiency. However, the $\mathrm{CO}_{2}$ at $20 \mathrm{MPa}$ has a $\sim 4 \%$ higher efficiency than the other cycles due to the decreased compression work for the cycle as seen in Table 2.1-2. Helium and nitrogen are insensitive to maximum system pressure while an efficiency gain can be accomplished by increasing the pressure for $\mathrm{CO}_{2}$.

The reduced compression work due to compression around the critical point of $\mathrm{CO}_{2}$ makes it an attractive option for a secondary working fluid. However, $\mathrm{CO}_{2}$ is not inert compared with other fluids such as helium and nitrogen and more advanced materials are required to address potential corrosion issues. The tradeoff of increased capital cost and increased cycle efficiency would need to be studied further if a more in-depth economic analysis were to be carried out.

Table 4 compares the cycle efficiency, the work duty of the turbine and compressor, and the total heat transfer area ratio for different working fluids in the power conversion unit. Pressure drops through the IHX and recuperator were calculated for various working fluids using a shell-tube type heat exchanger. Relative total area ratio can be varied depending on the final selection of heat exchanger. Overall heat transfer coefficients, $U$, were calculated and the ideal heat transfer area (assuming perfect counterflow) of the helium indirect cycle was used as a basis for comparing area ratios for each working fluid. As shown in Table 4, Nitrogen as a working fluid in the PCS needs the largest heat exchanger size compared with those of other fluids studied. The Framatome indirect cycle design therefore uses a helium-nitrogen mixture to increase the gas thermal conductivity and reduce the heat exchanger size.

UA was calculated using the following equation:

$$
\mathrm{U}_{\mathrm{i}}=\frac{1}{\frac{1}{\mathrm{~h}_{\mathrm{i}}}+\frac{\mathrm{D}_{\mathrm{i}}}{\mathrm{D}_{\mathrm{L}}} \frac{\mathrm{x}_{\mathrm{w}}}{\mathrm{k}_{\mathrm{m}}}+\frac{\mathrm{D}_{\mathrm{i}}}{\mathrm{D}_{\mathrm{o}} \mathrm{o}_{\mathrm{o}}}}
$$

where $U_{i}$ is an universal heat transfer coefficient based on an inner diameter, $h$ is the heat transfer coefficient, $x$ is thickness, $k$ is thermal conductivity, $i, O, L$ are inside, outside, and log-mean, respectively. $\mathrm{D}_{\mathrm{L}}$ is defined as:

$$
\mathrm{D}_{\mathrm{L}}=\frac{\mathrm{D}_{\mathrm{o}}-\mathrm{D}_{\mathrm{i}}}{\ln \left(\frac{\mathrm{D}_{\mathrm{o}}}{\mathrm{D}_{\mathrm{i}}}\right)}
$$


Table 4. Comparison of cycles for different working fluids

\begin{tabular}{|c|c|c|c|c|c|c|}
\hline Working Fluid & $\begin{array}{c}\text { Cycle } \\
\text { Efficiency }\end{array}$ & $\begin{array}{c}\text { Turbine } \\
\text { Work (MW) }\end{array}$ & $\begin{array}{c}\text { Compressor } \\
\text { Work (MW) }\end{array}$ & $\begin{array}{c}\text { Total UA } \\
(\mathrm{MW} / \mathrm{K})\end{array}$ & $\begin{array}{c}\text { Overall } \\
\mathrm{U} \\
\left(\mathrm{W} / \mathrm{m}^{2} \mathrm{~K}\right. \\
)\end{array}$ & $\begin{array}{c}\text { Total } \\
\text { Area } \\
\text { Ratio }\end{array}$ \\
\hline $\begin{array}{c}\text { He Direct (No } \\
\text { IHX) }\end{array}$ & $50.9 \%$ & 542.9 & 237.7 & Recup: 42.9 & 204.6 & 0.65 \\
\hline $\mathrm{He}$ Indirect & $48.7 \%$ & 575.4 & 256.5 & $\begin{array}{c}\text { IHX: } 24.2 \\
\text { Recup: } 43.1\end{array}$ & $\begin{array}{c}216.9 \\
204.6\end{array}$ & 1 \\
\hline $\mathrm{N}_{2}$ Indirect & $45.5 \%$ & 557.3 & 258.3 & $\begin{array}{c}\text { IHX: } 13.7 \\
\text { Recup: } 58.9\end{array}$ & $\begin{array}{c}186.7 \\
166.6\end{array}$ & 1.32 \\
\hline $\mathrm{CO}_{2}(20 \mathrm{MPa})$ & $50.7 \%$ & 497.2 & 167. & $\begin{array}{c}\text { IHX: } 24 \\
\text { Recup: } 35.1\end{array}$ & $\begin{array}{c}170.3 \\
145.3\end{array}$ & 1.18 \\
\hline
\end{tabular}

${ }^{1} \mathrm{UA}=$ Universal heat transfer coefficient ${ }^{*}$ heat transfer area, assuming perfect counterflow.

${ }^{2}$ Area Ratio: Total Heat Transfer Area of Working Fluid / Total Heat Transfer Area of Helium Indirect

Preliminary conclusions drawn from this investigation are:

- $\quad$ Among the three working fluids studied for the indirect PCS, supercritical $\mathrm{CO}_{2}$ has the highest cycle efficiency due to less compression work resulting from higher supercritical $\mathrm{CO}_{2}$ densities. . Supercritical $\mathrm{CO}_{2}$ also results in the smallest turbomachinary components.

- $\quad$ Helium direct cycle eliminates an IHX and consequently requires the smallest heat transfer area due to the higher heat capacity and thermal conductivity than those of other fluids.

- $\quad$ For the final selection of the best working fluid, or fluid mixture, trade-off studies need to be performed for efficiency, capital cost, maintenance cost, the stability of fluids through compressor, potential leakage from PCS, and other relevant issues. This project will include some of these issues later in FY-05 efforts.

\section{2-3-2 Effect of intercoolers}

The objective of this task is to find the cycle efficiency based on a variable number of intercooler in the secondary side of the HTGR or NGNP. In order to make a comparison with the supercritical $\mathrm{CO}_{2}$ cycle, cases using the helium Brayton cycle were made as a baseline. Then more complicated $\mathrm{CO}_{2}$ cycle will be investigated in the FY-05 first quarter, and will be reported next quarter.

To determine the effects of interstage cooling on cycle efficiency 1, 2 and 3 intercoolers were added to the basic indirect recuperated Helium cycle. The pressure drop through the precooler was set at $20 \mathrm{kPa}$. With a 1-intercooler layout the intercooler pressure drop was set to $50 \mathrm{kPa}$. With 2 intercoolers the first intercooler pressure drop was set to $37 \mathrm{kPa}$ and the second intercooler set to a pressure drop of $50 \mathrm{kPa}$. With a 3-intercooler 
layout the first, second and third intercooler pressure drops were set to 30,40 and 50 $\mathrm{kPa}$, respectively. These pressure drops were chosen because they are representative of pressure drops used in the MIT studied on an indirect Helium Brayton cycle with a maximum system pressure of $8 \mathrm{MPa}$ [Wang, 2003].

A base design for each cycle was determined and input into HYSYS. HYSYS was then used to simulate and optimize each cycle.

The base cycle used in this study was the indirect Helium cycle and the operating conditions used are summarized in Table 5. The efficiency without intercooling was $45.19 \%$. The efficiency with 1,2 and 3 intercoolers was $48.25 \%, 48.92 \%$ and $49.07 \%$, respectively.

Table 5 Cycle conditions used for intercoolers

\begin{tabular}{|l|l|}
\hline Condition & Value \\
\hline Reactor Power & $600 \mathrm{MW}$ \\
Reactor Outlet Temp & $900 \mathrm{C}$ \\
Turbine Polytropic Efficiency & $92 \%$ \\
Compressor Polytropic Efficiency & $90 \%$ \\
IHX Effectiveness & $90 \%$ \\
Recuperator Effectiveness & $95 \%$ \\
IHX Primary Side Pressure Drop & $150 \mathrm{kPa}$ \\
IHX Secondary Side Pressure Drop & $175 \mathrm{kPa}$ \\
Recuperator Hot Side Pressure Drop & $90 \mathrm{kPa}$ \\
Recuperator Cold Side Pressure Drop & $50 \mathrm{kPa}$ \\
Precooler Pressure Drop & $20 \mathrm{kPa}$ \\
Intercooler Pressure Drop & $30 \mathrm{kPa}$ \\
Compressor Inlet Temp & $28 \mathrm{C}$ \\
Pressure Ratio & 2.1 \\
\hline
\end{tabular}

\section{2-3-2 Effect of reheat}

The objective of this task is to determine how much a reheat option can enhance the cycle efficiency and to find out technical issues associated with the reheat option. For these calculations, a cycle similar to the proposed Advanced High Temperature (AHTR) (Forsberg et al., 2004, Peterson, 2002) was used with Flibe, a fluoride molten salt, as a coolant fluid in the primary side and helium in the Brayton cycle.

Theoretically a combination of reheat and intercooling increases the cycle efficiency in a closed cycle, the implications have not been explored. Multiple-reheat is technically viable for closed gas cycles, as demonstrated by the PBMR turbomachinary design with three separate turbines. For gas-cooled reactors, a multiple reheat option may not be practical due to higher-pressure loss associated with gases, i.e., helium, supercritical $\mathrm{CO}_{2}$, and nitrogen. However, molten coolants can transport heat with low pumping power requirement, which becomes very attractive without any consideration of material problems associated with molten coolants at high temperatures.

Figure 15 shows the layout of the HYSYS simulation. In the primary side, stream 1 to 6 has Flibe as a coolant and in the secondary side, streams 7 through 21 has helium as a working fluid. The cycle efficiency from this simulation is $56 \%$, which is much higher 
than helium-helium cycle or helium-CO2 cycle. The detailed operating conditions are summarized in Table 6 . Similar calculations are being performed now and it will be reported in the next quarterly report.

Table 6. Summary of HYSYS simulation with multiple reheats.

\begin{tabular}{|c|c|}
\hline & $\begin{array}{l}\text { Operating } \\
\text { conditions }\end{array}$ \\
\hline Reactor Power & $600 \mathrm{MW}$-thermal \\
\hline Configuration & Indirect \\
\hline $\begin{array}{l}\text { Mass flow of Flibe in the } \\
\text { primary loop }\end{array}$ & $1,189 \mathrm{~kg} / \mathrm{s}$ \\
\hline $\begin{array}{l}\text { Mass flow of helium in the } \\
\text { secondary loop }\end{array}$ & $295 \mathrm{~kg} / \mathrm{s}$ \\
\hline Reactor Inlet, stream (6) & $\frac{600^{\circ} \mathrm{C}}{0.1 \mathrm{MPa}(1 \mathrm{a}}$ \\
\hline \multirow{2}{*}{ Reactor Outlet, stream (1) } & $700^{\circ} \mathrm{C}$ \\
\hline & $0.1 \mathrm{MPa}(1 \mathrm{~atm})$ \\
\hline \multirow{2}{*}{$\begin{array}{l}\text { IHX Inlets (stream (2) to( } \\
5) \text { ) }\end{array}$} & $700^{\circ} \mathrm{C}$ \\
\hline & $0.1 \mathrm{MPa}(1 \mathrm{~atm})$ \\
\hline \multirow{2}{*}{$\begin{array}{l}\text { HP Turbine Inlet/Outlet } \\
(8) /(9)\end{array}$} & $602^{\circ} \mathrm{C} / 525 \mathrm{C}$ \\
\hline & $7 \mathrm{MPa} / 5.46 \mathrm{MPa}$ \\
\hline \multirow{2}{*}{$\begin{array}{l}\text { MP Turbine Inlet/Outlet } \\
(10) /(11)\end{array}$} & $622^{\circ} \mathrm{C} / 525 \mathrm{C}$ \\
\hline & $5.46 \mathrm{MPa} / 4 \mathrm{MPa}$ \\
\hline \multirow{2}{*}{$\begin{array}{l}\text { LP Turbine Inlet/Outlet } \\
(12) /(13)\end{array}$} & $622 \mathrm{C} / 525 \mathrm{C}$ \\
\hline & $4 \mathrm{MPa} / 2.93 \mathrm{MPa}$ \\
\hline \multirow{2}{*}{$\begin{array}{l}\text { Turbine Inlet/Outlet } \\
\text { (14)/(15) }\end{array}$} & $623^{\circ} \mathrm{C} / 525 \mathrm{C}$ \\
\hline & $\begin{array}{c}2.92 \mathrm{MPa} / 2.14 \\
\mathrm{MPa}\end{array}$ \\
\hline Recuperator Inlet/Outlet & $525 \mathrm{C} / 94 \mathrm{C}$ \\
\hline \multirow{2}{*}{ Compressor Inlet (17) } & $35^{\circ} \mathrm{C}$ \\
\hline & $2.5 \mathrm{MPa}$ \\
\hline \multirow{2}{*}{$\begin{array}{l}\text { LP Compressor Inlet } \\
\text { (18) }\end{array}$} & $35^{\circ} \mathrm{C}$ \\
\hline & $3.24 \mathrm{MPa}$ \\
\hline \multirow{2}{*}{$\begin{array}{c}\text { MP Compressor Inlet } \\
(19)\end{array}$} & $35^{\circ} \mathrm{C}$ \\
\hline & 4.2 MPa \\
\hline \multirow{2}{*}{$\begin{array}{c}\text { HP Compressor } \\
\text { Intlet/Outlet } \quad(20 / 21)\end{array}$} & $35^{\circ} \mathrm{C} / 73 \mathrm{C}$ \\
\hline & $\begin{array}{c}5.44 \mathrm{MPa} / 7.04 \\
\mathrm{MPa}\end{array}$ \\
\hline \multirow{2}{*}{$\begin{array}{l}\text { Outlet from Recuperator, } \\
\text { shell side }\end{array}$} & $5040^{\circ} \mathrm{C}$ \\
\hline & $7 \mathrm{MPa}$ \\
\hline Cycle Efficiency & $56 \%$ \\
\hline
\end{tabular}




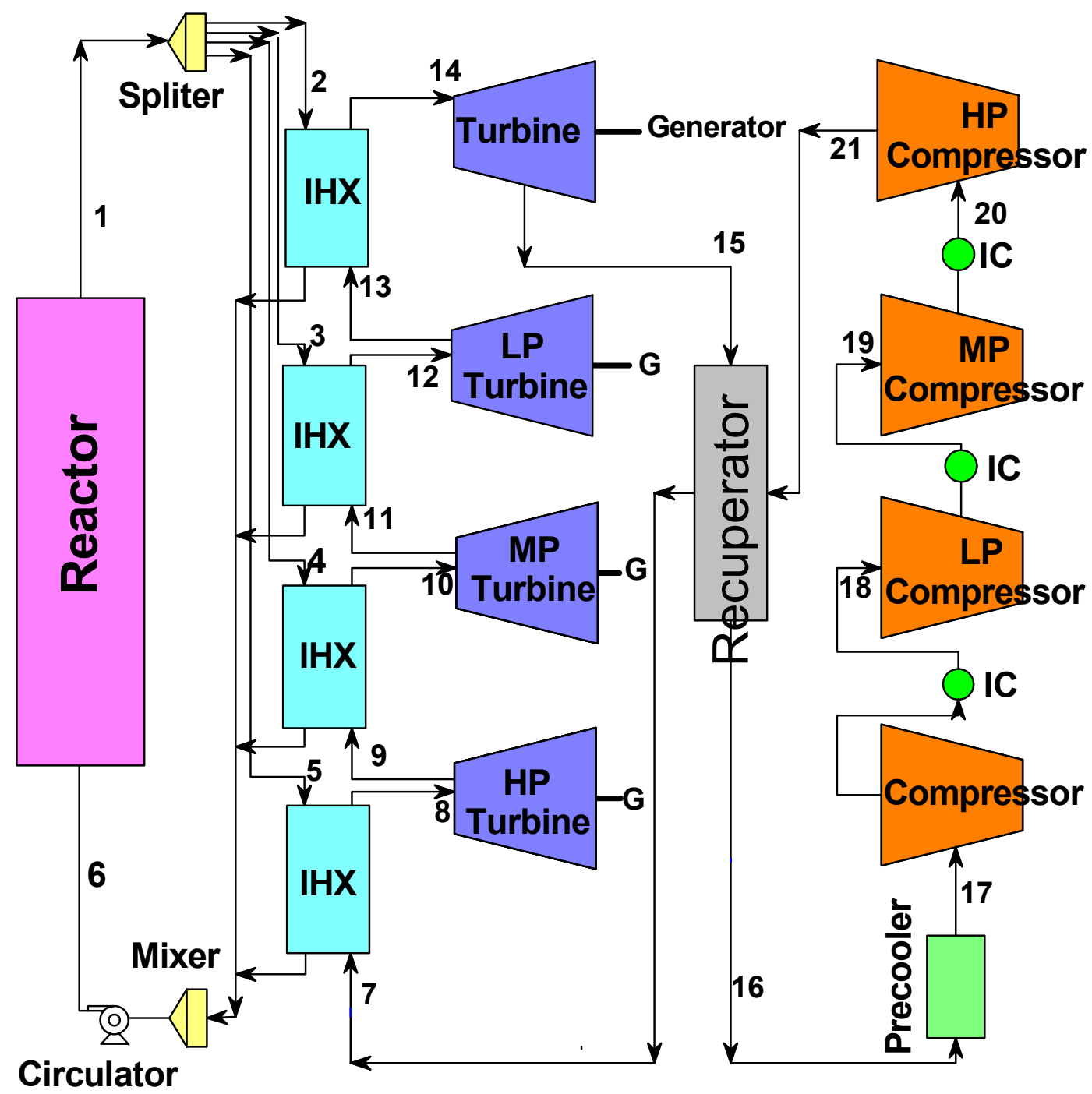

Figure 15. Cycle layout with multiple reheat option.

\section{Next quarter/year activities:}

- Task 2 continues with comparison of other cycle configurations.

- Other cycle configurations are a combined cycle, recompression, and multiple reheat cycle. The cycle will be optimized using HYSYS.

If time is allowed, an intermediate flow loop heat transfer study for NGNP hydrogen will be investigated.

Issues/concerns: There are no issues and/or concerns. 


\section{Task 3. Materials Testing}

Research on the creep behavior and corrosion resistance in supercritical $\mathrm{CO}_{2}$ of MA 754 continued during FY04. The creep behavior of both coarse-grained as well as finegrained MA 754 was documented. Creep microstructures were documented and fracture analysis was carried out on failed creep samples. A manuscript documenting the results was prepared and submitted to a peer-reviewed journal for publication.

Final modifications were made to a supercritical $\mathrm{CO}_{2}$ loop and the corrosion behavior of MA 754 in flowing supercritical $\mathrm{CO}_{2}$ at $1000^{\circ} \mathrm{C}$ and 1500 psi was documented.

Experiments were carried out at exposure times ranging from 47 to 335 hours. The time-averaged corrosion rate was found to decrease as the exposure time increased. The corrosion rate at the 335-hour exposure test equated to less than $1 \mathrm{~mm} / \mathrm{year}$. Microscopic examination indicated that a corrosion layer formed and grew slowly. The corrosion layer also acted to protect the base material from further corrosion.

Overall, it was concluded that MA 754 possessed high creep resistance at $1000^{\circ} \mathrm{C}$, better than other high temperature metallic alloys, and acceptable corrosion resistance to supercritical $\mathrm{CO}_{2}$. From these results it was determined that the study of creep and corrosion resistance of MA 758, that has a higher chromium content for added corrosion resistance, may not be necessary. This issue is being worked with the sponsor.

The detailed results of work performed during FY04 are given below for the various materials-related tasks.

\section{Task 3-1-2 High temperature mechanical and creep properties of coarse-grained MA} 754

During FY04, creep testing of annealed (coarse-grained) MA 754 specimens with both longitudinal and transverse orientations was completed. Creep and stress rupture data are graphically presented in Figures 16 through 19. In the longitudinal direction, high stress exponents are observed at the temperatures studied, consistent with the threshold behavior for this alloy. At a fixed stress, creep rates in the transverse orientation are much higher than in the longitudinal, in some cases greater than an order of magnitude. The stress exponents in the transverse direction decrease with increasing temperature; at temperatures of 900 and $1000^{\circ} \mathrm{C}$ the exponents are sufficiently low (less than 10) that threshold behavior is not observed. The reduction in stress exponent is believed to result from increased grain boundary diffusion and sliding at the higher temperatures. 


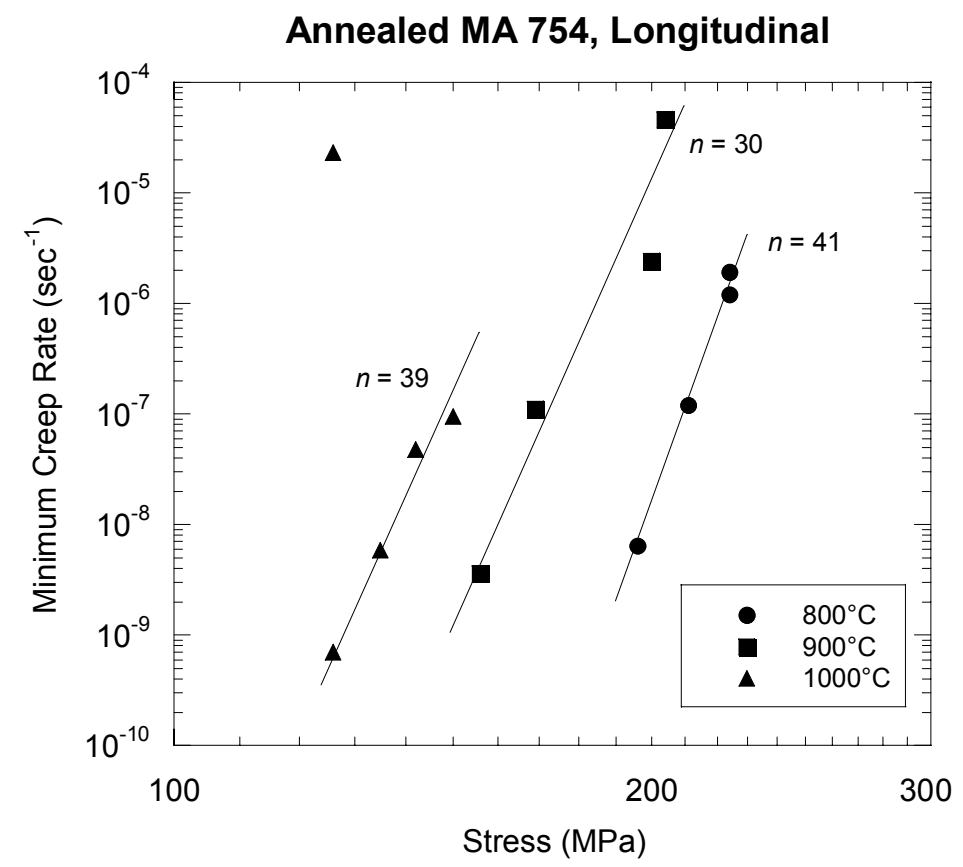

Figure 16: Minimum creep rates in coarse-grain MA 754, longitudinal orientation. Annealed MA 754, Transverse

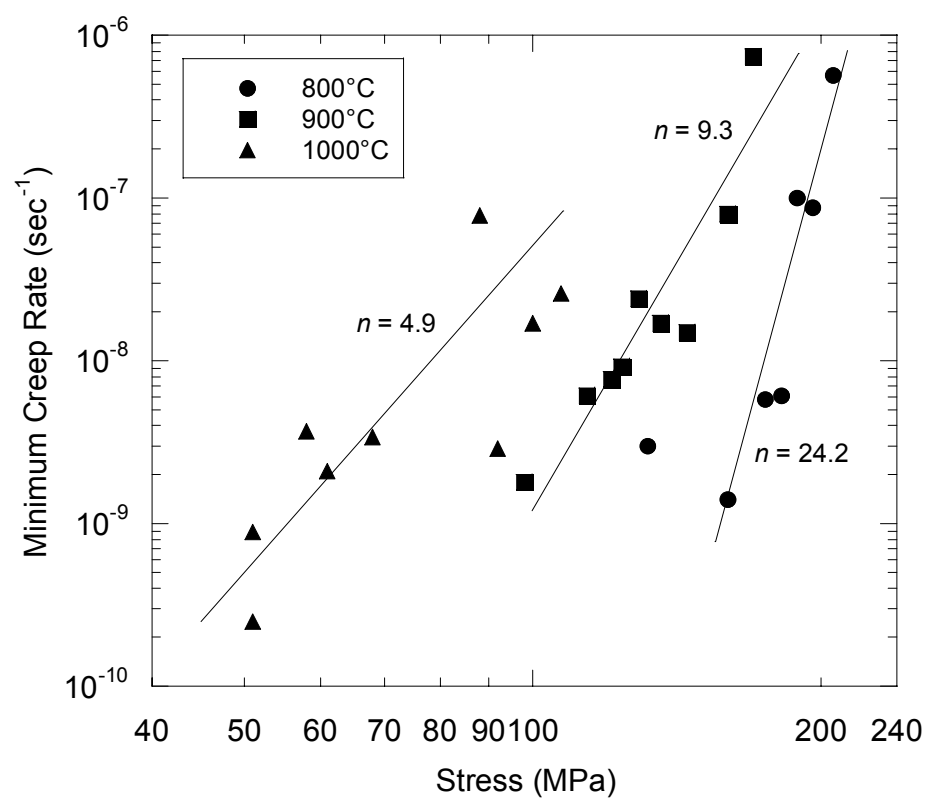

Figure 17: Minimum creep rates in coarse-grain MA 754, transverse orientation. 


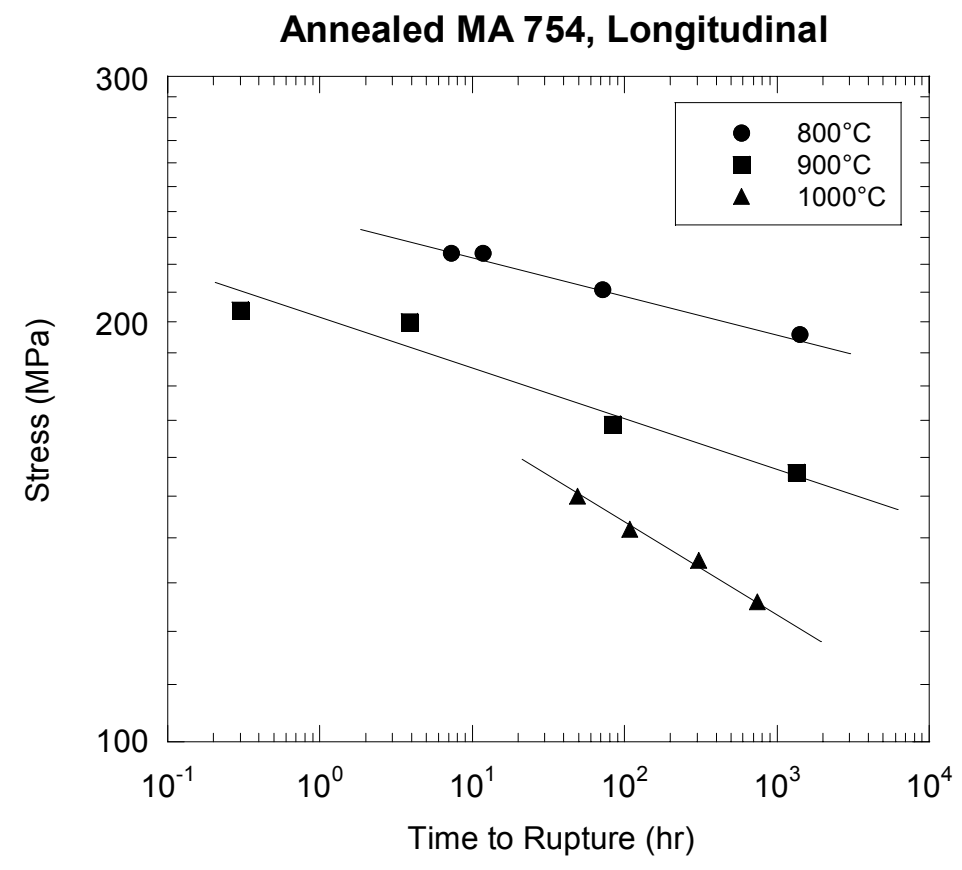

Figure 18: Stress-rupture behavior of coarse-grain MA 754, longitudinal orientation.

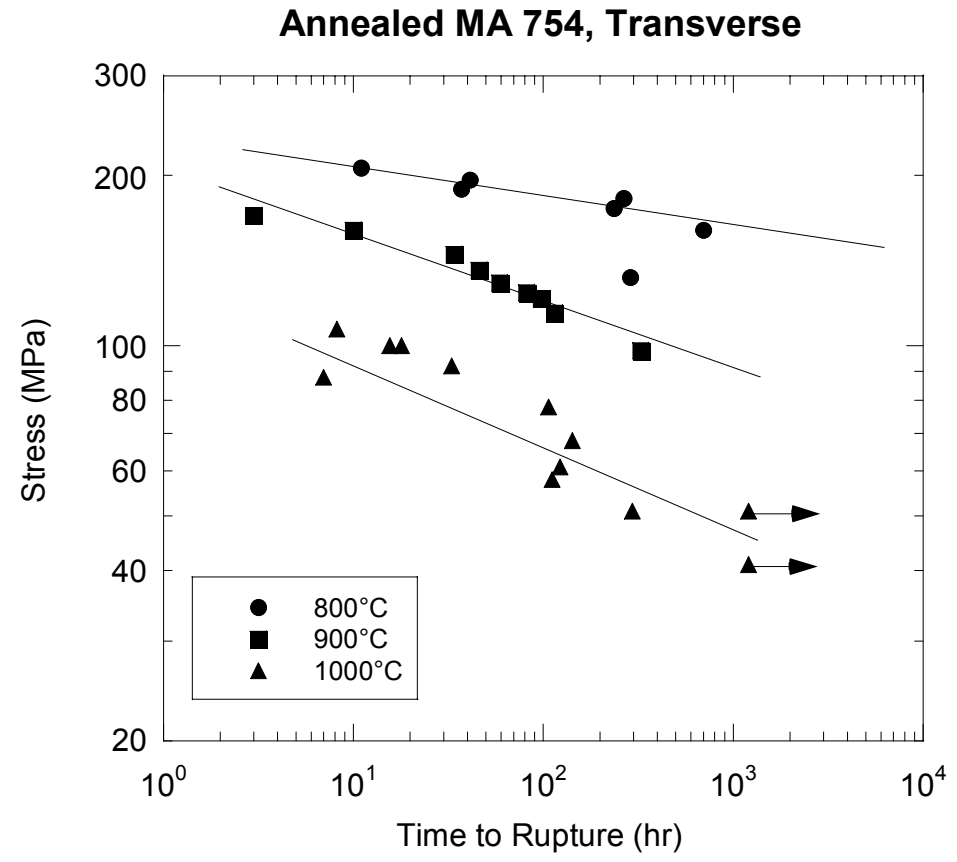

Figure 19: Stress-rupture behavior of coarse-grain MA 754, transverse orientation.

The creep and elevated temperature mechanical test data were summarized in a paper that was accepted for publication in Metallurgical and Materials Transactions $A$. The abstract of the paper follows: 
Terry C. Totemeier and Thomas M. Lillo, "Effect of Orientation on the Tensile and Creep Properties of Coarse-Grained INCONEL Alloy MA754".

Elevated temperature tensile and creep-rupture tests were performed on INCONEL MA754 in longitudinal and transverse orientations at temperatures from 700 to $1000^{\circ} \mathrm{C}$. Due to a higher grain boundary density perpendicular to the applied stress axis, the transverse orientation was weaker and less ductile than the longitudinal orientation. This effect was especially pronounced for creep tests at 900 and $1000^{\circ} \mathrm{C}$. Threshold creep behavior was observed for the longitudinal orientation with stress exponents ranging from 29 to 40 . Stress exponents in the long transverse orientation ranged from 24 at $800^{\circ} \mathrm{C}$ to 5 at $1000^{\circ} \mathrm{C}$, indicating a temperature-varying deformation mechanism. Creep ductility in the transverse direction was extremely low, less than $1 \mathrm{pct}$ for higher temperature, lower stress conditions. Failure was controlled by grain boundary separation for all transverse specimens. Despite the relative weakness of the transverse orientation, MA754 maintains a clear strength advantage over other wrought alloys being considered for advanced power plants.

The full paper is attached as an appendix since it gives greater detail and discussion of the results.

\section{Task 3-1-3 Mechanical and creep properties of fine-grained MA 754}

Fine grained MA754 was acquired from the vendor and characterization of the microstructure was performed. Fine-grained MA754 is heat treated at high temperature to produce coarse-grained (creep resistant) MA754. Figure 20 shows a TEM micrograph of fine-grained MA754 with the grain size on the order of 0.5-1.0 $\mu \mathrm{m}$. This is in contrast to the coarse-grained MA754, which exhibited highly elongated grains on the order of millimeters in length.

Tensile and creep specimens were fabricated to investigate the high temperature mechanical strength and creep resistance of this material.

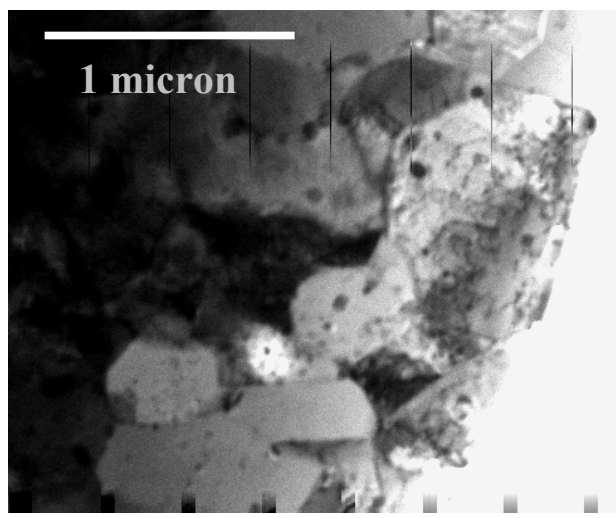

Figure 20. TEM micrograph of finegrained MA754. The creep resistance of the fine-grained MA754 is expected to be much lower than its large-grain counterpart. However, the creep properties of fine-grain MA754 must be known since joining may have to occur while in the fine grained state and then followed by an anneal to generate large creep resistant grains.

Elevated temperature tensile tests were completed on transverse specimens at 25, 800 , 900 , and $1000^{\circ} \mathrm{C}$ and a strain rate of $10^{-3} \mathrm{sec}^{-1}$. The test results are listed in Table 7. The fine-grained material is stronger than the coarse-grain material at room temperature ( $1275 \mathrm{MPa}$ vs. $900 \mathrm{MPa}$, respectively) but considerably weaker at elevated temperature $\left(67 \mathrm{MPa}\right.$ vs. $900 \mathrm{MPa}$ at $1000^{\circ} \mathrm{C}$, respectively). Transverse tensile ductility at elevated temperature is significantly higher than coarse-grain material $(\sim 20 \%$ vs. $\sim 10 \%$ at $1000^{\circ} \mathrm{C}$, respectively). 
Creep testing of fine-grained MA754 in the transverse orientation was also completed. The results indicate that the fine-grained material is significantly weaker than coarsegrained, even in the transverse orientation. The results of creep tests are listed in Table 8. The minimum creep rates for the fine-grained MA 754 for temperatures between 800 $1000^{\circ} \mathrm{C}$ are shown in Figure 21 . The stress exponents are slightly lower than those for the coarse-grain material in the transverse orientation.

Table 7: MA754 Fine-Grained Tensile Data

\begin{tabular}{lcccccc}
\hline Specimen & $\begin{array}{c}\text { Test Temperature } \\
\left({ }^{\circ} \mathrm{C}\right)\end{array}$ & $\begin{array}{c}\text { Modulus } \\
(\mathrm{GPa})\end{array}$ & $\begin{array}{c}\text { Yield Strength } \\
(\mathrm{MPa})\end{array}$ & $\begin{array}{c}\text { UTS } \\
(\mathrm{MPa})\end{array}$ & $\begin{array}{c}\text { Ductility } \\
(\%)\end{array}$ & $\begin{array}{c}\text { RA } \\
(\%)\end{array}$ \\
\hline \hline MA754F-T-1 & 25 & 225 & 1170 & 1257 & 7.7 & 16 \\
MA754F-T-2 & 25 & 231 & 1203 & 1297 & 8.8 & 18 \\
MA754F-T-3 & 800 & 47 & 118 & 138 & 40 & 46 \\
MA754F-T-4 & 800 & 39 & 141 & 148 & 40 & 45 \\
MA754F-T-5 & 900 & 27 & 90 & 91 & 32 & 51 \\
MA754F-T-6 & 900 & 39 & 86 & 89 & 38 & 49 \\
MA754F-T-7 & 1000 & 25 & 64 & 67 & 19 & 27 \\
MA754F-T-8 & 1000 & 35 & 60 & 65 & 19 & 34 \\
MA754F-T-9 & 1000 & 48 & 60 & 67 & 20 & 34 \\
\hline \hline
\end{tabular}

Table 8: MA754 Fine-Grained Creep Data - Transverse Orientation

\begin{tabular}{|c|c|c|c|c|c|c|c|}
\hline $\begin{array}{l}\text { Test/Specimen } \\
\text { ID }\end{array}$ & Orientation & $\begin{array}{c}\text { Test } \\
\text { Temperature } \\
\left({ }^{\circ} \mathrm{C}\right) \\
\end{array}$ & $\begin{array}{l}\text { Stress } \\
(\mathrm{MPa}) \\
\end{array}$ & $\begin{array}{c}\text { Minimum Creep } \\
\text { Rate } \\
\text { (sec-1) } \\
\end{array}$ & $\begin{array}{c}\text { Time to } \\
\text { Rupture } \\
\text { (hr) }\end{array}$ & $\begin{array}{c}\text { Ductility } \\
(\%) \\
\end{array}$ & $\begin{array}{l}\mathrm{RA} \\
(\%) \\
\end{array}$ \\
\hline MA754F-T-16 & Transverse & 800 & 45 & 5.40E-09 & 268 & 0.7 & 0 \\
\hline MA754F-T-15 & Transverse & 800 & 60 & 7.30E-08 & 35.4 & 1.5 & 0 \\
\hline MA754F-T-11 & Transverse & 800 & 74 & 7.90E-07 & 6.4 & 3.2 & 0 \\
\hline MA754F-T-12 & Transverse & 800 & 92 & & 0.9 & 13.5 & 15 \\
\hline MA754F-T-14 & Transverse & 900 & 25 & 3.10E-09 & 1138 & 2.4 & 0 \\
\hline MA754F-T-18 & Transverse & 900 & 35 & $3.50 \mathrm{E}-08$ & 105 & 1.6 & 0 \\
\hline MA754F-T-13 & Transverse & 900 & 45 & $1.70 \mathrm{E}-07$ & 15.4 & 1.6 & 0 \\
\hline MA754F-T-10 & Transverse & 900 & 64 & 5.50E-06 & 1.1 & 3.2 & 0 \\
\hline MA754F-T-17 & Transverse & 1000 & 10 & 7.80E-09 & $>1670$ & $>24$ & 0 \\
\hline MA754F-T-17 & Transverse & 1000 & 20 & 1.20E-07 & 83 & 5.4 & 0 \\
\hline
\end{tabular}




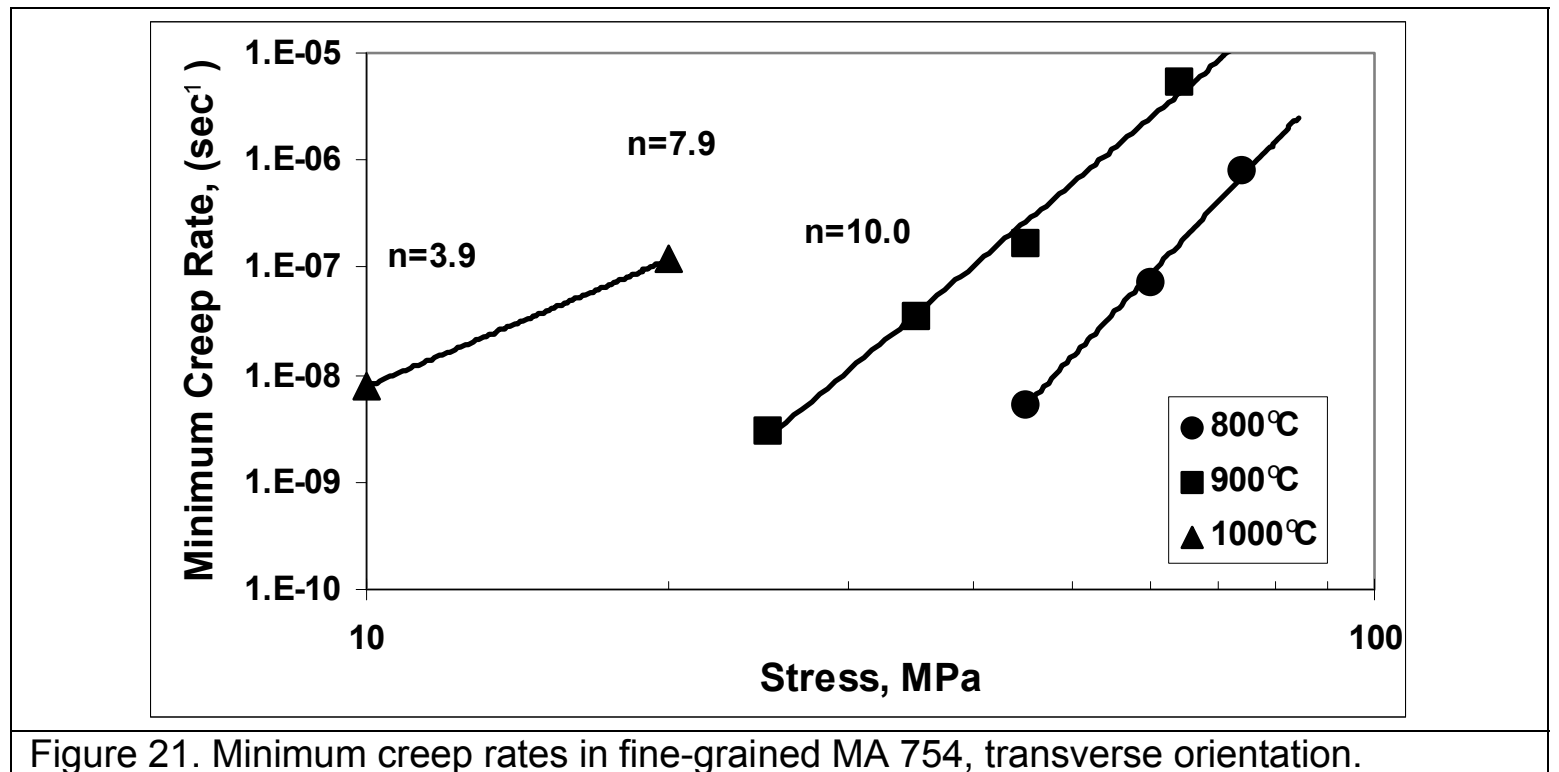

Task 3-2-2 Corrosion testing of MA 754 in supercritical $\mathrm{CO}_{2}$

Early in the first quarter of FY04 the first MA754 corrosion sample was put in the supercritical $\mathrm{CO}_{2}$ system and testing was initiated. Minor design and hardware deficiencies were found that were corrected before long-term corrosion testing in supercritical $\mathrm{CO}_{2}$ was carried out. An induction generator used to heat the sample was replaced with a high temperature box furnace, capable of reaching temperatures in excess of $1200^{\circ} \mathrm{C}$. Minor modifications to the sample and sample connection were also made to accommodate the change of heat sources. The system was reconnected and run. Details of the corrosion work are given below.

\section{$\underline{\text { Initial corrosion tests }}$}

An initial corrosion test of a coarse-grained MA754 sample in $\mathrm{CO}_{2}$ was conducted for 47 hours at 3000 psi and $1000{ }^{\circ} \mathrm{C}$. After 47 hours the sample developed a leak and was removed, sectioned longitudinally to show the inside wall of the sample tube and examined with an optical microscope. Preliminary analysis showed the formation of a thin corrosion layer on the inside walls. Detailed analysis directly adjacent to the outlet of the sample showed crack formation and evidence of corrosion/erosion within this specific area, Figures 22 and 23. This was unexpected since the connection was outside the hot zone of the furnace, although the flowing supercritical $\mathrm{CO}_{2}$ undoubtedly heated this connection to some extent.

This initial corrosion sample used a Swaglok ${ }^{\mathrm{TM}}$ type fitting to connect the high-pressure lines to the corrosion sample. As a consequence, the thin walled region of the sample was subjected to substantial compressive stresses when the fitting was tightened. The end fittings were redesigned to eliminate the stresses in this region since the cause of the observed intergranular cracking, e.g. over-tightening the fittings or cracking due to corrosion effects, could not be definitively determined. 


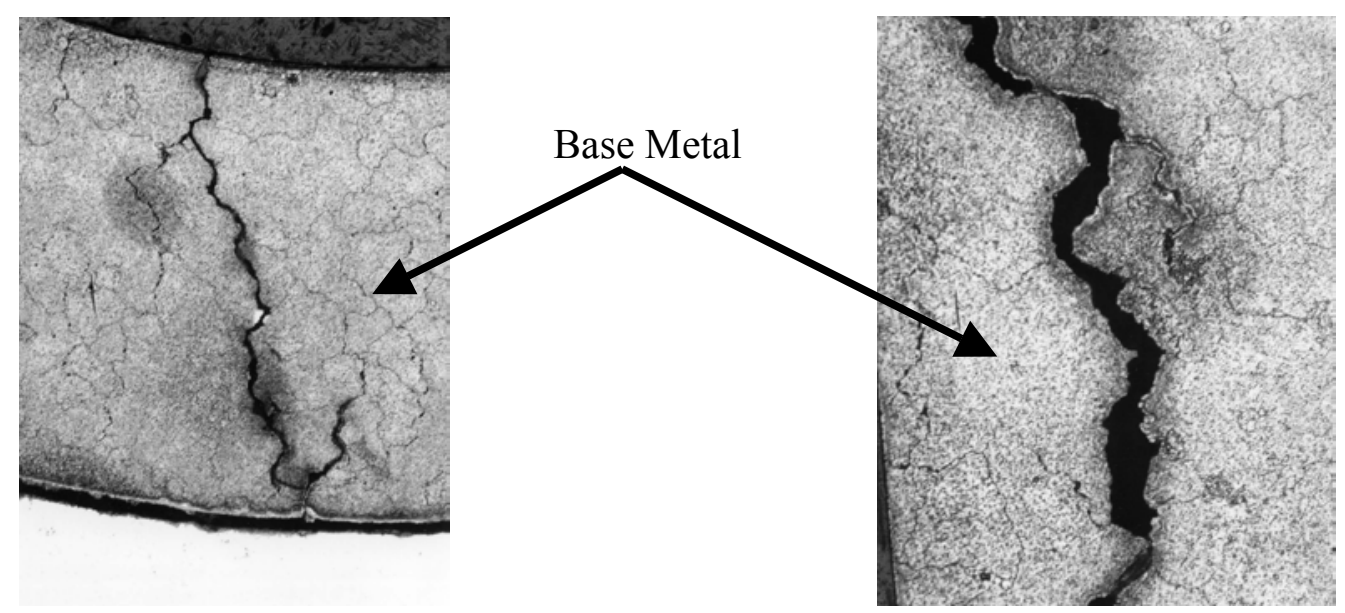

a.

b.

Figure 22: Cross section of the tube end after 47 hours at 3000 psi and $1000^{\circ} \mathrm{C}$. a) intergranular cracks shown in thin wall region at the end of the sample (100X) b) magnification of crack indicating material removal (200X).

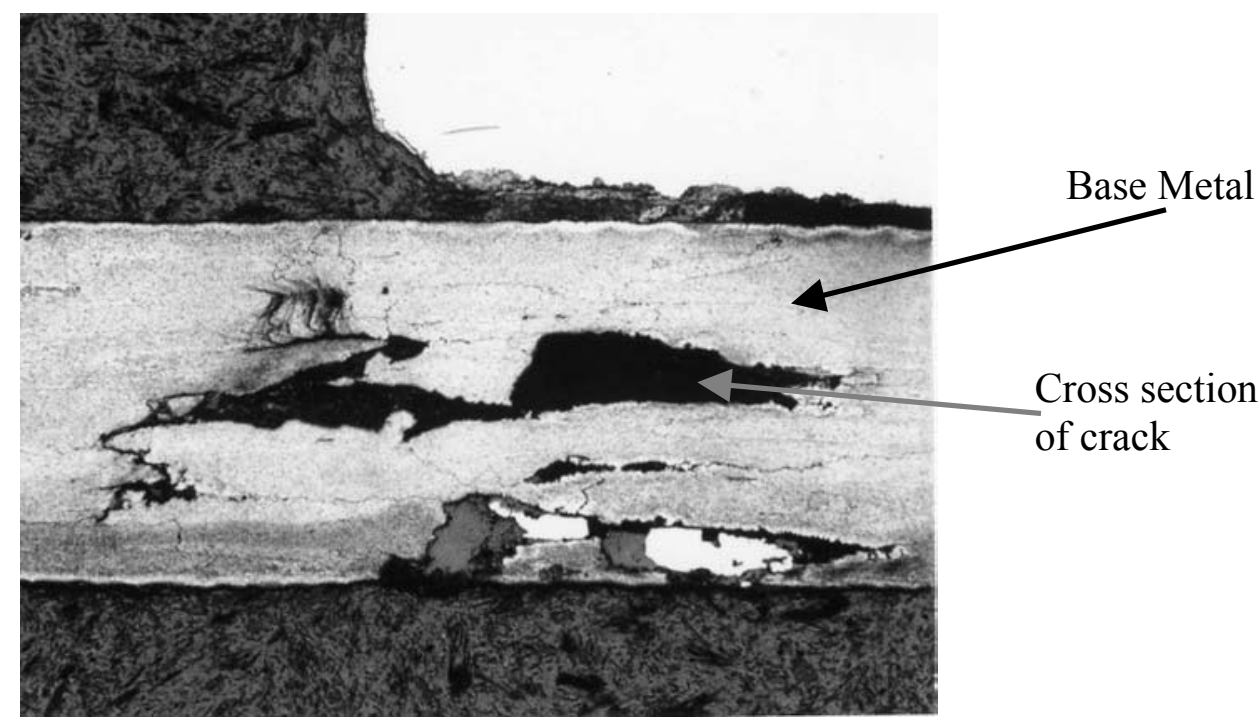

Figure 23: Cross-section of the end fitting after 47 hours at 3000 psi and $1000{ }^{\circ} \mathrm{C}$ showing significant material removal from central region of thin wall area (50X).

\section{Long-term corrosion tests $\left(1500 \mathrm{psi}-1000^{\circ} \mathrm{C}\right)$}

For the long-term corrosion tests the operating pressure was reduced to 1500 psi to more closely simulate the conditions used in Tasks 1 and 2. No cracks leading to premature leaks were detected at the ends of these samples that incorporated the new connection design. Two long-term corrosion tests were run, lasting 120 and 335 hours, respectively. 
Preliminary analyses of these much longer corrosion tests show a thin deposit on the inside of the sample tube that is quite uniform along its length. This is similar to the observations seen in the initial sample (tested at the same temperature, $1000^{\circ} \mathrm{C}$, but much higher pressure $-3000 \mathrm{psi}$ ). The surface deposit exhibited a green tint indicating the formation of nickel or chrome oxide on the inside walls of the samples. No indications of rapid corrosion mechanisms were observed (i.e. pitting, intergranular corrosion, spallation, etc). Following metallographic preparation, the corrosion layer was found to actually consist of two separate layers, the greenish outer layer and a much thinner layer adjacent to the base metal. Figure 24 shows this thin corrosion layer adjacent to the base metal. The green outer layer was quite soft and was inadvertently removed during metallographic preparation. Efforts are underway to stabilize the green outer layer during metallographic preparation so chemical analysis can be performed on both this layer and the thin layer adjacent to the base metal.

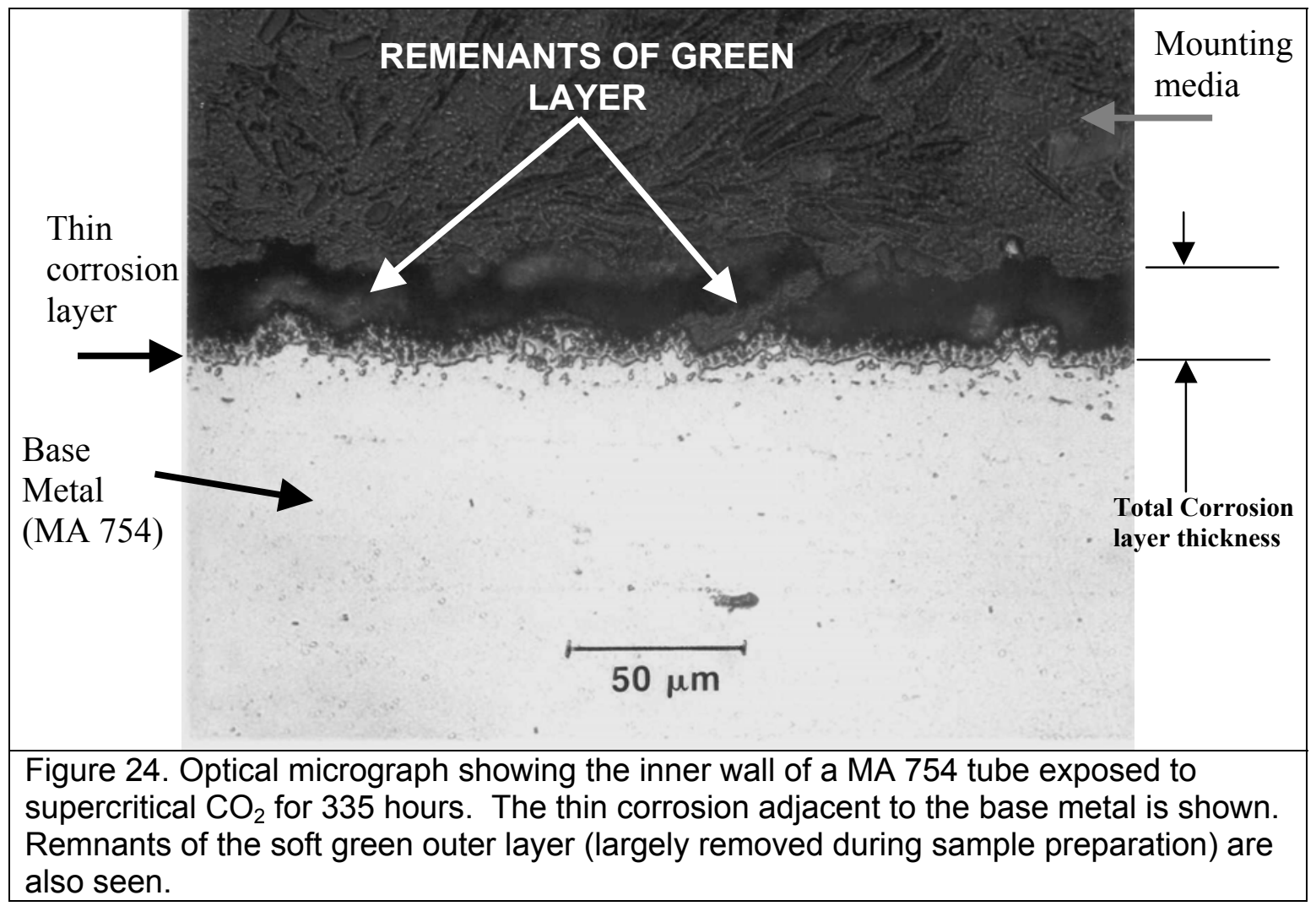

The thickness of the two corrosion layers was measured for the three samples exposed to supercritical $\mathrm{CO}_{2}$. The time-averaged corrosion rate for each sample was then calculated and reported in units of $\mathrm{mm} / \mathrm{year}$. Figure 25 shows the time-average corrosion rate as a function of exposure time for the combined corrosion layer (outer green layer plus the thinner layer adjacent to the base metal). At short exposure times the corrosion rate is quite high but as the exposure time increases the time-average corrosion rate decreases to quite low values. Therefore, it would appear that the growing corrosion layer provides protection from further corrosion. 


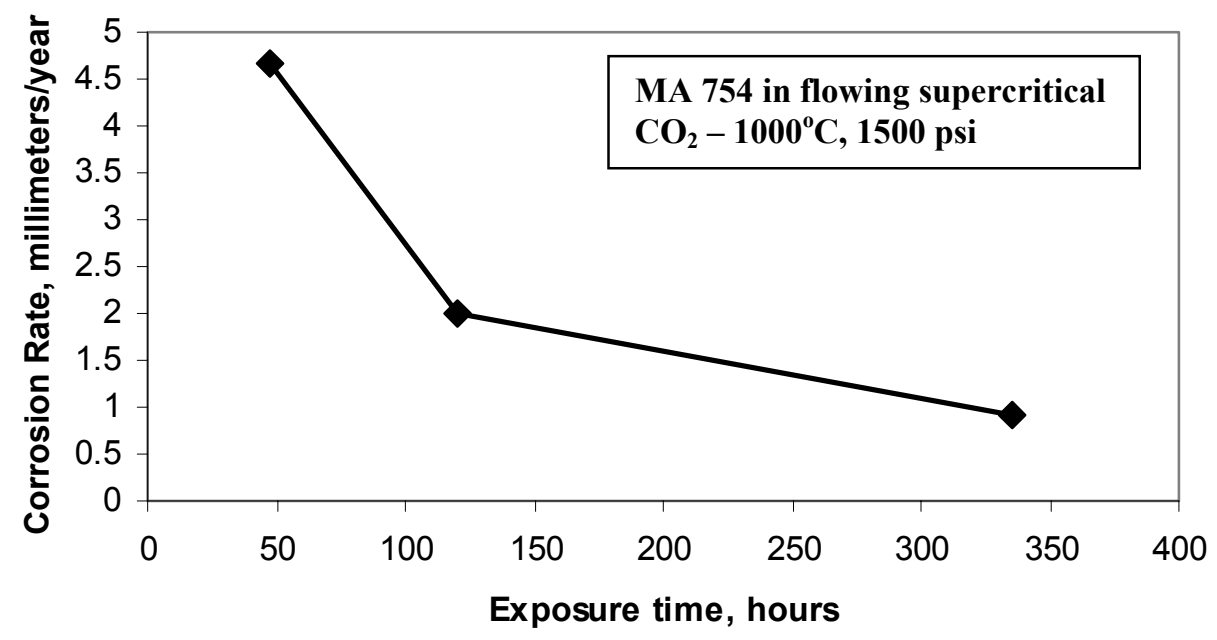

Figure 25. Plot of the time-averaged corrosion rate showing that further corrosion is slowed by the growing corrosion layer.

\section{Task 3-3 Summary report on MA 754}

Preparation of this report is in progress and largely complete. Only the compositional analysis of the corrosion layers shown in Figure 24 remains to be determined. The report will contain appropriate comparisons to other commercially available alloys. Also, the suitability of this alloy for the intended application will be discussed. This report should be completed early in the first quarter of FY05.

\section{Task 3-6 Analysis of creep microstructures in MA 754}

Failed creep specimens were prepared for metallographic study as well as electron microscopy. The fractographic and microscopic examinations of coarse-grained MA754 creep specimens were completed. The results of this examination were combined with creep and elevated temperature mechanical test data and incorporated into the manuscript mentioned under Task 3-1-2. As also mentioned, the manuscript has been accepted for publication in Metallurgical and Materials Transactions $A$ and has been attached at the end of this report as an appendix.

\section{Planned Activities}

- Complete Task 3-2-3 Corrosion testing of fine-grain MA 754 and compare the corrosion behavior to coarse-grained MA 754

- Initiate and complete Task 3-2-3 Corrosion testing of alternate alloys. Tentatively we plan on documenting the corrosion behavior of I-617, an alloy receiving considerable attention for use in various high temperature areas of the NGNP.

- Complete the summary report on MA 754 (Task 3-3) with recommendations on the suitability of MA 754 for use in a supercritical Brayton cycle.

Issues/concerns: There are no issues and/or concerns. 


\section{References}

Apspen Plus User's Manual, Aspentech Company, 2001.

Forsberg, C.W, P.F. Peterson, and L. Ott, The Advanced High-Temperature Reactor for Producing Hydrogen to Manufacture Liquid Fuels," ANES Paper, Miami Beach, FL., 2004.

GPSA Data Book, $11^{\text {th }}$ Edition, Gas Processors Suppliers Association, 1998.

Knapp H., "Vapor-Liquid Equilibria for Mixtures of Low Boiling Substances," Chemistry Data Series, Vol. VI, DECHEMA, 1989.

HYSYS User's Manual, Aspentech Company, 2001.

Macdonald, P.E., "NGNP Preliminary Point Design - Results of the Initial Neutronics and Thermal-Hydraulic Assessments, INEEL/EXT-03-00870, July 2003.

Oh, C.H and R.L. Moore, "Parametric Investigation of Brayton Cycle for High Temperature Gas-Cooled Reactors, HT-FED2004-56576, 2004 ASME Heat Transfer / Fluids Engineering Summer Conference, Charlotte, NC. July 11-15, 2004.

Peng, D.Y and D.B. Robison, "A Two Constant Equation of State," I.E.C. Fundamentals, 15, 1976, pp.59-64

Perry, R.H, D.W. Green, and J.O. Maloney, Perry's Chemical Engineers' Handbook, $7^{\text {th }}$ Edition, McGraw-Hill, 1997.

Peterson, P., "Multiple-Reheat Brayton Cycles for Nuclear Power Conversion with Molten Coolants," Nucl. Tech., 144, 2003, pp. 279-288.

Reid, R.C., J.M. Prausnitz, and T.K. Sherwood, 1977, The Properties of Gases and Liquids, Fourth Edition, McGraw-Hill Book Company, New York.

Reid, R.C., J.M. Prausnitz, and B.E. Poling, 1987, The Properties of Gases and Liquids, Third Edition, McGraw-Hill Book Company, New York.

Rivken, S.L, 1988, Thermodynamic Properties of Gases, Fourth Edition (Revised), Hemisphere Publishing Corporation.

Yan, X, T. Takakazu, S. Takada, K. Kunitomi, I. Minatsuki, and Y. Mizokami, "Cost and Performance Design Approach for GTHTR300 Power Conversion System," Nucl. Eng. \& Des., 226, 2003, pp. 351-373. 